\title{
STABILITY OF SPOT-DISTRIBUTION IN MANIOLA JURTINA THROUGHOUT ITS RANGE
}

\author{
W. H. DOWDESWELL \\ Biology Deportment, Winchester College \\ and \\ KENNEDY MCWHIRTER \\ 25 The Brood Walk, London, N.21*
}

Received I4.vi.66

\section{INTRODUCTION}

Our studies of evolution in the butterfly Maniola jurtina L. since 1946 have revealed something of the ways in which the insect becomes adjusted to the diversity of ecological conditions existing throughout its range. Ford (1964) has summarised all the principal references. As an index of variation we have used the distribution of spots on the underside of the hind-wings (ranging from o to 5 per wing) - -a character now known to be under polygenic control (McWhirter, in preparation). Throughout this paper we have considered the species jurtina solely from the point of view of the spot-values. We do not here express any opinion on the validity of various taxonomic schemes which have been proposed for it. Our thesis is that spot-stabilisations transcend specific and possibly generic boundaries.

One of the outstanding facts emerging from our investigations is that spot-distribution achieves a remarkable stability even in the face of a highly diverse and fluctuating environment. This is true of both males and females, but since the female is the more variable sex, it provides the better indicator of adjustment to changing conditions. Thus, across the whole of Southern England ranging from the cold, dry east coast to the warmer, humid conditions of mid-Devon (a distance of about 230 miles) we find a characteristic stabilisation with the males unimodal at 2 spots and the females unimodal at $o$.

Sampling of the jurtina populations in the vicinity of the DevonCornwall border during 1956 revealed an unexpected situation in which the typical Southern English stabilisation changed to a different Cornish one in a matter of a few yards and in the absence of any detectable ecological barrier (Creed et al., 1959). Thus, while the change in male spotting amounted to little more than an increase in spot-average, that of the females became bi-modal at o and 2 spots. During the subsequent nine years the situation has remained much the same except that the zone of transition has moved by somewhat erratic steps 22 miles eastwards, to a locality 9 miles west of Crediton.

\footnotetext{
* Present address: Genetics Laboratory, Department of Zoology, Oxford.
} 


\section{CONTINUITY OF SPOT-DISTRIBUTION IN SPACE AND TIME}

There is a number of questions which, if answered, could throw much valuable light on evolution in the butterfly:

(i) How far does the Southern English stabilisation extend eastwards?

(ii) What other stabilisations occur throughout the insect's range in Europe, Asia and Africa?

(iii) For how long have these various stabilisations existed?

(iv) In what circumstances (outside Britain) does one form of stabilisation change into another?

With these questions in mind, we studied collections of Maniola jurtina in the British Museum (Natural History). It seems that nearly all the collections represent effectively random samples; certainly no attention appears to have been paid by collectors to the relatively insignificant spots on the underside of the hind-wings. Our treatment of the collections as valid samples so far as spots are concerned has yielded consistent and interesting patterns of spot-distribution. Even rather small collections have been scored and listed, since they either contribute to a general picture of the situation over wide areas and long periods of time, or, at least, suggest some deviation from the expected pattern. Their use, however, has inevitably meant a certain sacrifice of statistical rigour in the comparison of samples with respect to their homogeneity. Throughout the paper we have emphasised the significance of the spot-average as a parameter providing a reliable index of general trends in spot-distribution.

Some populations are subject to intra-seasonal shift. For instance, at Ipswich in 1957 the early emergence was rather highly spotted but was succeeded by typical lower spotting (Old English pattern) later on (Creed et al., 1959). A similar change occurs regularly in certain populations near Winchester (Dowdeswell, I961, I962). Samples collected in single or neighbouring localities in the General European area (see pp. I9o to 197 below) do not show any evidence of intraseasonal shift, which suggests that the phenomenon may be confined to populations on the periphery of the Continent as a whole.

\section{THE BRITISH ISLES}

\section{(a) Ireland}

The data for 1920 and 1932 show that the characteristic Irish stabilisation, with an overwhelmingly high mode at o spots in the females, goes back at least 40 years (table I). The male samples of I920 do not show the expected degree of low spotting.

\section{(b) Scotland}

A new sample from Gairloch, Wester Ross, obtained in I929, can now be added to the record and compared with that taken in 1959 (Creed et al., I962). 
This population appears to be very stable and fits the general observation that Northern Scotland conforms with the "Old English" stabilisation (Forman, Ford and McWhirter, 1959).

TABLE I

Spot-distributions and spot-averages in eight samples of M. jurtina from Ireland

Results reported by Creed et al. (1962) are incorporated.

\begin{tabular}{|c|c|c|c|c|c|c|c|c|c|c|c|}
\hline \multirow{2}{*}{ Locality } & \multirow{2}{*}{ Year } & & \multicolumn{6}{|c|}{ Spots } & \multirow{2}{*}{ Total } & \multicolumn{2}{|c|}{ Spot-average } \\
\hline & & & o & I & 2 & 3 & 4 & 5 & & Female & Male \\
\hline Sligo & 1920 & q & 8 & I & $\ldots$ & $\ldots$ & $\ldots$ & $\ldots$ & 9 & $0 \cdot I$ & \\
\hline Kerry & 1920 & ठ & $\cdots$ & $\begin{array}{l}2 \\
2\end{array}$ & $\begin{array}{l}8 \\
I\end{array}$ & $\begin{array}{l}2 \\
1\end{array}$ & $\begin{array}{r}\text { I } \\
\ldots\end{array}$ & $\begin{array}{l}\ldots \\
\ldots\end{array}$ & $\begin{array}{l}\text { I3 } \\
\text { I3 }\end{array}$ & 0.5 & \\
\hline & & ot & $\ldots$ & 2 & 4 & 2 & $\ldots$ & $\ldots$ & 8 & 3 & $2 \cdot 0$ \\
\hline Kerry & $\begin{array}{c}\mathrm{I} 932 \\
\text { (mainly) }\end{array}$ & 우 & $2 I$ & 4 & 3 & 2 & $\cdots$ & $\cdots$ & 30 & 0.5 & \\
\hline Cork & $\begin{array}{c}1932 \\
\text { (mainly) }\end{array}$ & q & 21 & I & 3 & 2 & $\cdots$ & $\cdots$ & 27 & 0.5 & \\
\hline Longford & $195 \mathrm{I}$ & q & 30 & 2 & 2 & $\cdots$ & $\ldots$ & $\cdots$ & 34 & 0.2 & \\
\hline Co. Galway & $195^{2}$ & 要 & $\begin{array}{l}16 \\
21\end{array}$ & $\begin{array}{r}24 \\
\text { I }\end{array}$ & $\begin{array}{r}29 \\
2\end{array}$ & $\begin{array}{l}10 \\
\ldots\end{array}$ & $\begin{array}{l}\cdots \\
\cdots\end{array}$ & $\cdots$ & $\begin{array}{l}79 \\
24\end{array}$ & 0.2 & \\
\hline & & 8 & 19 & 9 & 23 & 4 & $\cdots$ & $\cdots$ & 55 & & $1 \cdot 2$ \\
\hline Cliffony, Sligo & I $95^{8}$ & o & 24 & I & $\dddot{8}$ & $\cdots$ & $\cdots$ & $\cdots$ & $\begin{array}{r}25 \\
26\end{array}$ & $0 \cdot 04$ & $\cdot 6$ \\
\hline Aran Islands, & & 0 & & 7 & 10 & 3 & $\cdots$ & $\cdots$ & & & \\
\hline Co. Galway & I959 & 우 & I 4 & $\cdots$ & $\cdots$ & $\cdots$ & $\cdots$ & $\cdots$ & I 4 & nil & \\
\hline
\end{tabular}

(c) Southern England

No collections of large numbers from the same area were found, nor were there any early collections of reasonable size.

TABLE 2

Comparison of samples from Gairloch, Wester Ross, 1929 and 1959

\begin{tabular}{|c|c|c|c|c|c|c|c|c|c|c|}
\hline \multirow{2}{*}{ Year } & & \multicolumn{6}{|c|}{ Spots } & \multirow{2}{*}{ Total } & \multicolumn{2}{|c|}{ Spot-average } \\
\hline & & o & I & 2 & 3 & 4 & 5 & & Female & Male \\
\hline $\begin{array}{r}\text { I929 } \\
\text { I } 959\end{array}$ & $\begin{array}{l}\text { o } \\
+ \\
0 \\
+ \\
0 \\
0\end{array}$ & $\begin{array}{r}15 \\
\ldots \\
20 \\
2\end{array}$ & $\begin{array}{l}4 \\
5 \\
8 \\
5\end{array}$ & $\begin{array}{r}4 \\
8 \\
5 \\
\mathrm{I} 3\end{array}$ & $\begin{array}{l}\text { I } \\
4 \\
3 \\
7\end{array}$ & $\begin{array}{r}\cdots \\
\cdots \\
\cdots \\
\\
\end{array}$ & $\begin{array}{l}\ldots \\
\cdots \\
\cdots \\
\cdots\end{array}$ & $\begin{array}{l}24 \\
17 \\
36 \\
28\end{array}$ & & $\begin{array}{l}2 \cdot 0 \\
2 \cdot 0\end{array}$ \\
\hline
\end{tabular}

These collections reflect faithfully the situation in Southern England before the wave of high spotting in 1955-58. The excess of females at two spots over those at one spot in the Tring collection is clearly not significant and the spot-averages conform well with the "Old English" 
stabilisation. It could be that the Hockley sample is in fact showing a tendency to slightly higher spotting. This has been noticed in males from eastern England, but not in females (McWhirter, 1957).

TABLE 3

Museum samples of M. jurtina from Southern England

\begin{tabular}{|c|c|c|c|c|c|c|c|c|c|c|c|}
\hline \multirow{2}{*}{ Locality } & \multirow{2}{*}{ Year } & & \multicolumn{6}{|c|}{ Spots } & \multirow{2}{*}{ Total } & \multicolumn{2}{|c|}{ Spot-average } \\
\hline & & & 0 & I & 2 & 3 & 4 & 5 & & Female & Male \\
\hline $\begin{array}{l}\text { Tring area } \\
\text { Hockley, Essex }\end{array}$ & $\begin{array}{c}1947-48 \\
\text { I922 } \\
\text { (mainly) }\end{array}$ & $\begin{array}{l}0 \\
+ \\
0 \\
0 \\
+ \\
0\end{array}$ & $\begin{array}{r}40 \\
5 \\
8 \\
\ldots\end{array}$ & $\begin{array}{l}7 \\
6 \\
4 \\
1\end{array}$ & $\begin{array}{r}8 \\
38 \\
4 \\
9\end{array}$ & $\begin{array}{l}4 \\
6 \\
1 \\
\text { I }\end{array}$ & $\begin{array}{r}\ldots \\
3 \\
\ldots \\
\ldots\end{array}$ & $\begin{array}{l}\cdots \\
\cdots \\
\cdots \\
\cdots\end{array}$ & $\begin{array}{l}59 \\
58 \\
\text { I } 7 \\
\text { I I }\end{array}$ & $\begin{array}{l}0.59 \\
0.9\end{array}$ & $\begin{array}{l}I \cdot 93 \\
2 \cdot 0\end{array}$ \\
\hline
\end{tabular}

\section{THE "GENERAL EUROPEAN" (GE) STABILISATION AREA}

Samples taken between I 890 and 1936 from a large part of continental Europe always have females with a mode at o spots and males with a mode of 2 spots (tables 4-6). This area (see map at p. 193) is roughly square with sides $2500 \mathrm{~km}$. (I 500 miles) long. Such a span in space and time gives plenty of opportunity for the kind of " secondorder" variation, which we have found in Britain, to manifest itself. In fact, the female samples show some heterogeneity and the males much more. If, however, three geographical sub-areas are defined, all samples, except three on the periphery, fall into place. The relatively slight differences between the sub-areas hardly vitiate the concept of a huge area of stabilisation. It seems that rather uniform and very strong selection pressures are operating to produce similar spot-distributions from year to year in many localities. That it is possible for the insect to adopt other patterns of spotting is of course clear from examples already reported from the Isles of Scilly and Cornwall and from Ireland; there is now additional evidence of this inherent variability from the countries lying to the south of the General European area (see map at p. 193). Yet there is no sign of any radical deviations within it, despite its size and the long period over which the museum samples were obtained.

Owing to the large number of samples from the GE area, we decided in the first place to adopt a geographical basis of subdivision. This procedure is objectively justified by the homogeneity of males and females in each sub-area, judged by their spot-distributions (and see Tables I2(a) and (b)). The three sub-areas are the north and central (GENC) region, the south-easterly region (GESE) and the southwesterly region (GESW). Between these sub-areas there are considerable differences in the adjustment of male spotting, though this never loses the GE characteristic of a mode at 2 spots. The females are 
modal at o spots and more uniform, though only those of GENC and GESE are homogeneous. In this matter, the large continental part of the GE area resembles the intensively studied south English region; for there, between $195^{\circ}$ and 1952, females were homogeneous but males

TABLE 4

Spot-distributions of M. jurtina samples from the Northern and Central parts of the General European stabilisation area $(G E N C)$

\begin{tabular}{|c|c|c|c|c|c|c|c|c|c|c|}
\hline & & \multicolumn{6}{|c|}{ Spots } & \multirow[b]{2}{*}{ Total } & \multicolumn{2}{|c|}{ Spot-average } \\
\hline & & 0 & I & 2 & 3 & 4 & 5 & & 우 & o \\
\hline $\begin{array}{l}\text { Inga, Finland, } \\
\text { 5.vii.35 } \\
\text { Het Zoute, Belgium, } \\
\text { 30.vi.3o } \\
\text { Liège, Belgium, } \\
\text { 28.vii.25, 9.vii.27 } \\
\text { Hannover, Germany, } \\
\text { 26.vii..29 } \\
\text { Salzdetfurth, nr. Hannover, } \\
\text {-.viii.o6 } \\
\text { Lahr-in-Baden, Black Forest, } \\
\text {-.vii.29 } \\
\text { Bad Wörishofen, nr. Munich, } \\
\text {-.vii.o5 mainly } \\
\text { Meissen, nr. Dresden, } \\
\text { ? } \\
\text { Bad Reinerz, nr. Breslau, } \\
\text { end vii, early viii? } \\
\text { Mödling, nr. Vienna, } \\
\text { I928 } \\
\text { Brno, Czechoslovakia, } \\
\text { ? } \\
\text { Kaposvar, Hungary, } \\
\text { ? } \\
\text { Baie Herkulane, Romania, } \\
\text { I go7 } \\
\text { Csehtelek, Bihar, Romania, } \\
\text { I go8, I go9, I 9I I }\end{array}$ & $\begin{array}{l}9 \\
+ \\
0 \\
0 \\
0 \\
0 \\
0 \\
0 \\
0 \\
0 \\
0 \\
0 \\
+ \\
0 \\
0 \\
0 \\
0 \\
0 \\
0 \\
0 \\
0 \\
0 \\
0 \\
0 \\
0 \\
0 \\
0 \\
0 \\
0 \\
0 \\
0 \\
0 \\
0 \\
0 \\
0 \\
0 \\
0 \\
0 \\
0 \\
0 \\
0 \\
0 \\
0 \\
0\end{array}$ & \begin{tabular}{c}
27 \\
$\ldots$ \\
4 \\
$\ldots$ \\
2 \\
$\ldots$ \\
22 \\
$\ldots$ \\
I \\
$\ldots$ \\
\hdashline \\
8 \\
I \\
7 \\
$\ldots$ \\
I5 \\
$\ldots$ \\
7 \\
$\ldots$ \\
$\ldots$ \\
$\ldots$ \\
I2 \\
$\ldots$ \\
I5 \\
$\ldots$ \\
8 \\
$\ldots$ \\
I
\end{tabular} & $\begin{array}{r}9 \\
\cdots \\
\mathrm{I} \\
\mathrm{I} \\
2 \\
\ldots \\
\mathrm{I} 5 \\
5 \\
6 \\
\ldots \\
5 \\
2 \\
\mathrm{I} \\
\mathrm{I} \\
3 \\
\cdots \\
4 \\
\ldots \\
2 \\
\ldots \\
7 \\
\mathrm{I} \\
\mathrm{I} \\
\ldots \\
\cdots \\
\mathrm{I} \\
4\end{array}$ & $\begin{array}{r}3 \\
6 \\
2 \\
10 \\
10 \\
1 \\
9 \\
3 \\
23 \\
3 \\
4 \\
2 \\
19 \\
\ldots \\
20 \\
4 \\
7 \\
1 \\
5 \\
5 \\
1 \\
\text { I0 } \\
\ldots \\
\text { I } \\
\text { I } \\
9 \\
9 \\
1 \\
13 \\
2\end{array}$ & $\begin{array}{r}\ldots \\
\ldots \\
\ldots \\
3 \\
\ldots \\
\mathrm{I} \\
\mathrm{I} \\
\ldots \\
\ldots \\
\ldots \\
\cdots \\
\mathrm{I} \\
\ldots \\
4 \\
2 \\
\ldots \\
\ldots \\
\ldots \\
\ldots \\
\ldots \\
\ldots \\
3 \\
\mathrm{C} \\
\mathrm{I} \\
3 \\
\mathrm{I} \\
\mathrm{I} \\
\mathrm{I}\end{array}$ & $\begin{array}{c}\ldots \\
\ldots \\
\ldots \\
\text { I } \\
\ldots \\
\ldots \\
\ldots \\
4 \\
\ldots \\
\ldots \\
\ldots \\
2 \\
\ldots \\
\ldots \\
\ldots \\
\ldots \\
\ldots \\
\ldots \\
\ldots \\
\ldots \\
\ldots \\
\ldots \\
\ldots \\
\ldots \\
\ldots\end{array}$ & $\begin{array}{c}\ldots \\
\ldots \\
\ldots \\
\ldots \\
\ldots \\
\ldots \\
\ldots \\
\ldots \\
\ldots \\
\ldots \\
\ldots \\
\ldots \\
\ldots \\
\ldots \\
\ldots \\
\ldots \\
\ldots \\
\ldots \\
\ldots \\
\ldots \\
\ldots \\
\ldots \\
\ldots\end{array}$ & $\begin{array}{r}39 \\
6 \\
7 \\
15 \\
5 \\
10 \\
41 \\
32 \\
26 \\
4 \\
15 \\
25 \\
8 \\
25 \\
24 \\
7 \\
12 \\
5 \\
8 \\
10 \\
19 \\
21 \\
18 \\
12 \\
10 \\
15 \\
18\end{array}$ & $\begin{array}{c}0.4 \\
(0.7) \\
(0.8) \\
0.6 \\
0.5 \\
0.6 \\
(0.1) \\
0.7 \\
0.5 \\
(0.5) \\
0.4 \\
0.3 \\
0.5 \\
0.6\end{array}$ & $\left(\begin{array}{l}(2 \cdot 0)^{*} \\
2 \cdot 3 \\
2 \cdot I \\
2 \cdot I \\
(2 \cdot 0) \\
2 \cdot 0 \\
2 \cdot I \\
(2 \cdot 0) \\
(2 \cdot 0) \\
(2 \cdot 0) \\
2 \cdot I \\
2 \cdot 5 \\
2 \cdot 0\end{array}\right.$ \\
\hline $\begin{array}{l}\text { Female total } \\
\text { Male total }\end{array}$ & $\frac{q}{q}$ & $\begin{array}{r}160 \\
I\end{array}$ & $\begin{array}{l}60 \\
I I\end{array}$ & $\begin{array}{r}24 \\
152\end{array}$ & $\begin{array}{r}6 \\
16\end{array}$ & $\cdots$ & $\cdots$ & $\begin{array}{l}250 \\
187\end{array}$ & 0.5 & $2 \cdot 1$ \\
\hline
\end{tabular}

* When samples are of fewer than ro specimens, estimates of spot-average in this and subsequent tables are bracketed.

differed significantly between a slightly higher spotted eastern group and a lower spotted western group (McWhirter, I957). After the great and exceptional disturbances which began in 1955, this second-order distinction has not re-established itself in south England. The continental part of the GE area seems to exhibit more stability than the English (see p. I95 below) and it may well be that the second-order variations in the males there will have persisted up to date. 
TABLE 5

Spot-distributions of M. jurtina samples from the South-eastern parts of the General European stabilisation area (GESE)

\begin{tabular}{|c|c|c|c|c|c|c|c|c|c|c|}
\hline & & \multicolumn{6}{|c|}{ Spots } & \multirow{2}{*}{ Total } & \multicolumn{2}{|c|}{ Spot-average } \\
\hline & & 0 & I & 2 & 3 & 4 & 5 & & $q$ & $\sigma^{\pi}$ \\
\hline $\begin{array}{l}\text { Sofia,* Bulgaria, } \\
\text { 29.vii.32 } \\
\text { Mount Vitosh, nr. Sofia, } \\
\text { 20.vii.22 } \\
\text { Pravadiya, Bulgaria, } \\
\text { I932 } \\
\text { Senj, Yugoslavia, } \\
\text {-.vii. } 3 \text { mainly }\end{array}$ & $\begin{array}{l}0 \\
+ \\
0 \\
0 \\
+ \\
0 \\
0 \\
+ \\
0 \\
0 \\
0 \\
0 \\
0\end{array}$ & $\begin{array}{r}18 \\
\cdots \\
6 \\
\cdots \\
7 \\
\cdots \\
9 \\
\cdots\end{array}$ & $\begin{array}{r}\text { II } \\
\cdots \\
2 \\
\cdots \\
5 \\
\cdots \\
4 \\
\cdots\end{array}$ & $\begin{array}{r}3 \\
7 \\
\ldots \\
4 \\
2 \\
5 \\
2 \\
45\end{array}$ & $\begin{array}{r}\ldots \\
2 \\
\ldots \\
1 \\
1 \\
4 \\
\ldots \\
17\end{array}$ & $\begin{array}{r}\ldots \\
2 \\
\ldots \\
\ldots \\
\ldots \\
\ldots \\
\ldots \\
5\end{array}$ & $\begin{array}{l}\ldots \\
\cdots \\
\cdots \\
\cdots \\
\cdots \\
\mathrm{I} \\
\cdots \\
\mathrm{I}\end{array}$ & $\begin{array}{r}32 \\
11 \\
8 \\
5 \\
15 \\
10 \\
15 \\
68\end{array}$ & $\begin{array}{c}0.5 \\
(0.3) \\
0.8 \\
0.5\end{array}$ & $\begin{array}{c}2 \cdot 5 \\
(2 \cdot 2) \\
(2 \cdot 7) \\
2 \cdot 4\end{array}$ \\
\hline $\begin{array}{l}\text { Female total } \\
\text { Male total }\end{array}$ & $\begin{array}{l}0 \\
0 \\
0\end{array}$ & $\begin{array}{l}40 \\
\cdots\end{array}$ & $\begin{array}{l}22 \\
\cdots\end{array}$ & $6_{I}^{7}$ & $\begin{array}{r}I \\
24\end{array}$ & $\dddot{7}$ & ${ }_{2}$ & $\begin{array}{l}70 \\
94\end{array}$ & 0.6 & $2 \cdot 5$ \\
\hline
\end{tabular}

* V. Dimitrov records exact site as Tsar Boris's garden.

TABLE 6

Spot-distributions of M. jurtina samples from the South-western parts of the General European stabilisation area $(G E S W)$

\begin{tabular}{|c|c|c|c|c|c|c|c|c|c|c|}
\hline & & \multicolumn{6}{|c|}{ Spots } & \multirow[b]{2}{*}{ Total } & \multicolumn{2}{|c|}{ Spot-average } \\
\hline & & o & 1 & 2 & 3 & 4 & 5 & & 우 & $\sigma^{1}$ \\
\hline $\begin{array}{l}\text { Château d'Oex, nr. Montreux, } \\
\text { Switzerland, } \\
28 . v i i .07,5 . v i i i .07 \\
\text { St Martin-Vésubie, nr. Nice, } \\
\text { 6.vii.29 } \\
\text { Digne, Basses Alpes, France, } \\
\text { I9.vi.o8 } \\
\text { Vernet-les-Bains, East Pyren- } \\
\text { ees, France, } \\
\text { vii.91-94, vii.96 } \\
\text { Vernet-les-Bains, vii.1 go9 } \\
\text { Royan, Charente Inférieure, } \\
\text { France, I 924-29 } \\
\text { St Jean-de-Monts, Vendée, } \\
\text { France, I5.vi.21 } \\
\text { Rennes, Brittany, France, } \\
\text { I896, 1905-6 }\end{array}$ & $\begin{array}{l}\text { o } \\
0 \\
+ \\
0 \\
0 \\
+ \\
0 \\
0 \\
0 \\
+ \\
\overrightarrow{0}\end{array}$ & $\begin{array}{c}\mathrm{I} 3 \\
9 \\
\ldots \\
35 \\
\ldots \\
28 \\
\ldots\end{array}$ & $\begin{array}{r}5 \\
3 \\
1 \\
11 \\
1 \\
8 \\
\ldots\end{array}$ & $\begin{array}{r}7 \\
4 \\
12 \\
4 \\
5 \\
7 \\
23\end{array}$ & $\begin{array}{r}2 \\
2 \\
2 \\
2 \\
3 \\
2 \\
12\end{array}$ & $\begin{array}{c}\ldots \\
\ldots \\
\mathrm{I} \\
\ldots \\
\mathrm{I} \\
\ldots \\
5\end{array}$ & $\begin{array}{l}\text { I } \\
\ldots \\
\ldots \\
\ldots \\
\ldots \\
\cdots \\
\cdots\end{array}$ & $\begin{array}{r}7 \\
21 \\
12 \\
29 \\
15 \\
20 \\
135 \\
\\
28 \\
18 \\
16 \\
52 \\
10 \\
45 \\
40\end{array}$ & $\begin{array}{c}(0.3) \\
0.9 \\
0.5 \\
0.65 \\
\\
1 \cdot 1 \\
1 \cdot 0 \\
0.5 \\
0.6\end{array}$ & $\begin{array}{l}2 \cdot 3 \\
2 \cdot 7 \\
2 \cdot 7\end{array}$ \\
\hline $\begin{array}{l}\text { Female total } \\
\text { Male total }\end{array}$ & $\begin{array}{l}q \\
0 \\
0\end{array}$ & $\begin{array}{l}194 \\
\cdots\end{array}$ & $\begin{array}{r}52 \\
5\end{array}$ & $\begin{array}{l}49 \\
75\end{array}$ & $\begin{array}{l}13 \\
40\end{array}$ & $\begin{array}{r}2 \\
15\end{array}$ & $\begin{array}{l}2 \\
1\end{array}$ & $\begin{array}{l}312 \\
136\end{array}$ & $0 \cdot 66$ & 2.5 \\
\hline
\end{tabular}




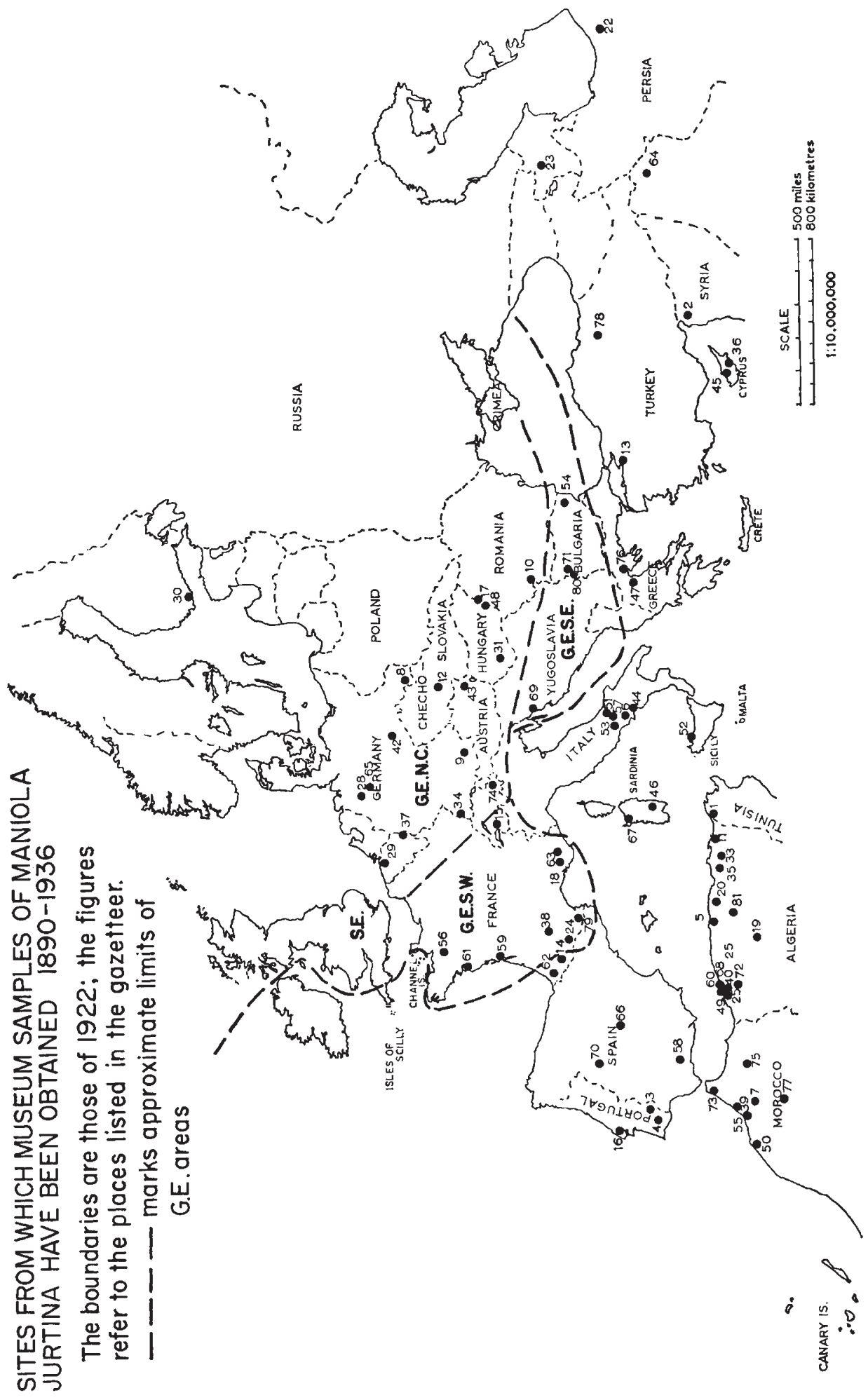


(a) The General European (Northern and Central) sub-area (GENC)

This runs from the northern limits of the insect's distribution to include Finland, Germany, Poland, Austria, Czechoslovakia, Hungary and Romania. Belgium is provisionally included, though on the few data available, it might also adhere to the more south-westerly group.

TABLE 7

Spot-distribution of M. jurtina samples from the Northern and Central parts of the General European stabilisation area $(G E \mathcal{N} C)$, up to 1935

\begin{tabular}{|c|c|c|c|c|c|c|c|c|c|}
\hline \multirow{2}{*}{ Per cent. } & \multicolumn{6}{|c|}{ Spots } & \multirow{2}{*}{ Total } & \multicolumn{2}{|c|}{ Spot-average } \\
\hline & 0 & I & 2 & 3 & 4 & 5 & & 우 & ๘ \\
\hline $\begin{array}{l}\text { Females } \\
\text { Males }\end{array}$ & $\begin{array}{r}64 \\
I\end{array}$ & $\begin{array}{r}24 \\
6\end{array}$ & $\begin{array}{l}\text { ro } \\
81\end{array}$ & $\begin{array}{l}2 \\
9\end{array}$ & $\begin{array}{c}\ldots \\
3\end{array}$ & $\begin{array}{l}\cdots \\
\cdots\end{array}$ & $\begin{array}{l}250 \\
197\end{array}$ & 0.5 & $2 \cdot I$ \\
\hline
\end{tabular}

Scotland evidently also belongs here, but while southern England conformed up to I952 and the "Old English" (OE) stabilisation was similar to GENC, some parts of this region switched to a rather more highly spotted stabilisation, "New English" (NE), after the wave of high spotting which occurred in 1955-57. Clearly, in the enlarged temporal and geographical scale with which we are now dealing, England is a relatively unstable (perhaps because peripheral) region.

TABLE 8

Spot-distribution of M. jurtina samples from southern England, 1950-52 (OE stabilisation)

\begin{tabular}{|c|c|c|c|c|c|c|c|c|c|}
\hline \multirow{2}{*}{ Per cent. } & & \multicolumn{5}{|c|}{ Spots } & \multirow{2}{*}{ Total } & \multicolumn{2}{|c|}{ Spot-average } \\
\hline & o & $\mathrm{I}$ & 2 & 3 & 4 & 5 & & q & $\sigma^{*}$ \\
\hline Females & 63 & 21 & $12 \cdot 5$ & 3 & 0.5 & $\cdots$ & 820 & $0 \cdot 5^{8}$ & \\
\hline Males (western group) & 5 & 13 & 74 & 7 & I & $\ldots$ & $39 I$ & & $\mathrm{I} \cdot 86$ \\
\hline Males (eastern group) & 3 & II & 67 & $16 \cdot 5$ & $I \cdot 5$ & I & 309 & & $2 \cdot 06$ \\
\hline
\end{tabular}

Normal percentage values for spot-numbers in the GENC sub-area and the absolute numbers obtained from museum collections up to I 935 are given in table 7; further details are listed in table 4 (see also map and gazetteer at pp. I93 and 209).

Examination of tables 7 to 9 shows that, while the GENC and OE females are homogeneous $\left(\chi_{(3)}^{2}=3.0 ; 0.5>\mathrm{P}>0.1\right)$, the GENG males are significantly heterogeneous when compared with males from either 
the eastern flank or the western flank of the OE stabilisation area. This is clearly partly due to the very high mode at 2 spots among the GENC males and this feature might indeed be symptomatic of much more stringent stabilisation on the Continent. The various GENG male samples deviate only very narrowly from the spot-average of $2 \cdot I$ (table 4).

TABLE 9

Comparison of GENC males with $O E$ males from eastern and western groups of southern England (as defined in McWhirter, 1957)

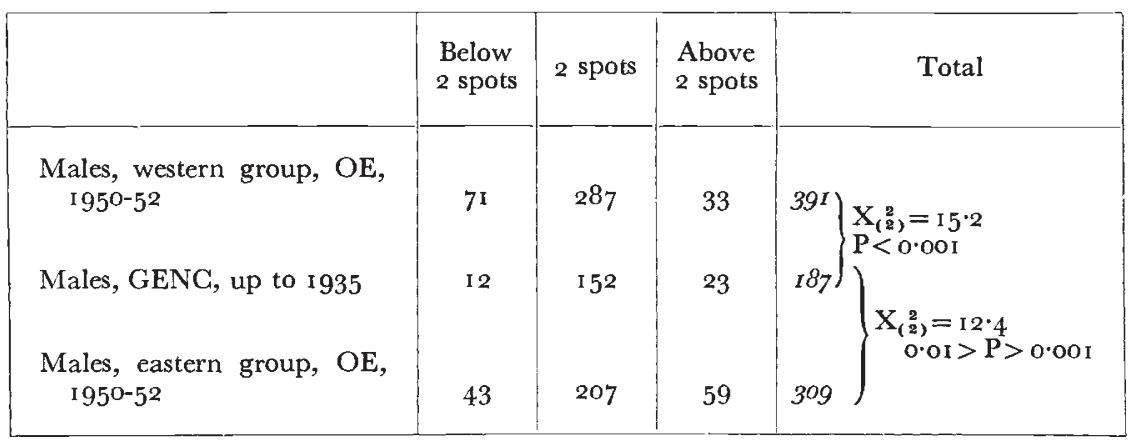

(b) The General European (South-eastern) sub-area (GESE)

Four samples from Bulgaria and Yugoslavia have been scored; their female spotting does not differ significantly from that of the GENC sub-area, though it may be fractionally higher $\left(\chi_{(\mathbf{2})}^{\mathbf{2}}=\mathrm{r} \cdot 6\right.$; $0.5>\mathrm{P}>0 . \mathrm{I}$; see tables 5 and I2). The males, on the other hand, are much more highly spotted and no specimens with less than two spots were found. The difference between GENG and GESE males is strongly significant with $\chi_{(1)}^{2}=18 \cdot 9 ;$ and $\mathrm{P} \ll 0 \cdot 00 \mathrm{I}$.

The boundaries of the GESE sub area judged by the few data available correspond very approximately to the territories of Bulgaria and Yugoslavia. To the south, a sample from Macedonia and Thessaloniki does not conform to the GE stabilisation (table I5) and to the north, samples from Mödling, near Vienna, Kaposvar in south-west Hungary and two collections from Romania seem to fit the GENC pattern quite well.

Percentage values for spot-numbers in the GESE sub-area and the absolute numbers obtained from museum collections up to 1932 are given in table 10 , and further details are listed in table 5. The sites are recorded in the map and gazetteer (pp. 193 and 209).

(c) The General European (South-western) sub-area (GESW)

Eight samples from western Switzerland and from southern and western France were scored (see table 6). Two of these were from the same locality (Vernet-les-Bains); one was assembled during the last decade of the nineteenth century and the other was taken in r 909 . 
Only females were seen; there may have been a rise in spotting in the interval but the difference between the samples is not significant $\left(\chi_{(2)}^{2}=3.5 ; 0.2>P>0.1\right)$.

To test the seven localities for homogeneity, it is necessary, because of small numbers, to limit the comparison to "o spot" and "spotted" categories. Also the samples from Château d'Oex and St MartinVésubie have only a few females, and these are combined with the

TABLE Io

Spot-distributions of M. jurtina samples from the South-eastern parts of the General European stabilisation area (GESE), up to $193^{2}$

\begin{tabular}{|c|c|c|c|c|c|c|c|c|c|}
\hline \multirow{2}{*}{ Per cent. } & \multicolumn{6}{|c|}{ Spots } & \multirow{2}{*}{ Total } & \multicolumn{2}{|c|}{ Spot-average } \\
\hline & 0 & I & 2 & 3 & 4 & 5 & & 우 & పే \\
\hline $\begin{array}{l}\text { Females } \\
\text { Males }\end{array}$ & $\begin{array}{l}57 \\
\ldots\end{array}$ & $\begin{array}{l}31 \\
\cdots\end{array}$ & $\begin{array}{l}\text { ro } \\
65\end{array}$ & $\begin{array}{r}2 \\
26\end{array}$ & $\begin{array}{r}\cdots \\
7\end{array}$ & ... & $\begin{array}{l}70 \\
94\end{array}$ & $0 \cdot 6$ & $2 \cdot 5$ \\
\hline
\end{tabular}

nearest collection, that from Digne. This gives $\underset{(4)}{2}=2 \cdot 4$; $0.7>\mathrm{P}>0.5$, and suggests a high degree of homogeneity. In the case of the males, St Jean de Monts is represented by only ro specimens, so these are combined with the sample from Rennes. This produces a $2 \times 5$ table, with males at 3,4 and 5 spots grouped against those at 2 or less than 2 spots. Thus $\underset{(4)}{2}=7.64$ and $0.2>\mathrm{P}>0.1$. Thus it appears that both males and females are homogeneous in the GESW sub-area.

TABLE I I

Spot-distribution of M. jurtina samples from the South-western parts of the General European stabilisation area $(G E S W)$, up to 1929

\begin{tabular}{|c|c|c|c|c|c|c|c|c|c|}
\hline \multirow{2}{*}{ Per cent. } & \multicolumn{6}{|c|}{ Spots } & \multirow{2}{*}{ Total } & \multicolumn{2}{|c|}{ Spot-average } \\
\hline & o & I & 2 & 3 & 4 & 5 & & q & 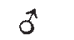 \\
\hline $\begin{array}{l}\text { Females } \\
\text { Males }\end{array}$ & $\begin{array}{l}62 \\
\ldots\end{array}$ & $\begin{array}{r}17 \\
4\end{array}$ & $\begin{array}{l}\text { I } 6 \\
55\end{array}$ & $\begin{array}{r}4 \\
29\end{array}$ & $\begin{array}{r}0.5 \\
\text { II }\end{array}$ & $\begin{array}{r}0.5 \\
I\end{array}$ & $\begin{array}{l}312 \\
136\end{array}$ & $0 \cdot 66$ & $2 \cdot 5$ \\
\hline
\end{tabular}

Some of the female samples in this group would fit the GENG pattern as well as the GESW one. Château d'Oex, Digne, St Jean de Monts and Rennes all show fairly low female spot-average. In each case, however, the male spot-averages are markedly above the norm for GENC.

Percentage values for spot numbers in the GESW sub-area and the absolute numbers obtained from museum collections up to 1929 are given in table I $\mathrm{r}$; further details are listed in table 6 (see also map and 
gazetteer at pp. I93 and 209). As in the case of the GESE males, those from GESW are extremely heterogeneous when compared with GENG males; $\underset{(2)}{2}=35 ; \mathrm{P}<0 \cdot 00 \mathrm{I}$.

\section{(d) Synopsis of the GE area}

We have made comparisons (see table I2) between the males of the three sub-areas and a similar one between the females. The GESE

TABLE 12

Comparisons between male and female samples of $\mathrm{M}$. jurtina from the three $G E$ sub-areas

\begin{tabular}{|c|c|c|c|c|}
\hline & $\begin{array}{l}\text { Below } \\
2 \text { spots }\end{array}$ & 2 spots & $\begin{array}{l}\text { Above } \\
2 \text { spots }\end{array}$ & \\
\hline $\begin{array}{l}\text { GENC } \\
\text { GESE }\end{array}$ & $\begin{array}{l}12 \\
\cdots\end{array}$ & $\begin{array}{r}152 \\
61\end{array}$ & $\begin{array}{l}23 \\
33\end{array}$ & \}$x_{(1)}^{2}=18.9 ; \quad P<0.001$ \\
\hline $\begin{array}{l}\text { GENC } \\
\text { GESW }\end{array}$ & $\begin{array}{r}12 \\
5\end{array}$ & $\begin{array}{r}152 \\
75\end{array}$ & $\begin{array}{l}23 \\
56\end{array}$ & \}$x_{(2)}^{2}=36 \cdot 0 ; P<0.001$ \\
\hline $\begin{array}{l}\text { GESE } \\
\text { GESW }\end{array}$ & $\begin{array}{c}\cdots \\
5\end{array}$ & $\begin{array}{l}61 \\
75\end{array}$ & $\begin{array}{l}33 \\
56\end{array}$ & \}$x_{(1)}^{2}=0.6 ; 0.5>P>0.1$ \\
\hline \multicolumn{5}{|c|}{ (b) Female } \\
\hline & o spot & I spot & $\begin{array}{c}2 \text { and } \\
>2 \text { spots }\end{array}$ & \\
\hline $\begin{array}{l}\text { GENC } \\
\text { GESE }\end{array}$ & $\begin{array}{r}160 \\
40\end{array}$ & $\begin{array}{l}60 \\
22\end{array}$ & $\begin{array}{r}30 \\
8\end{array}$ & \}$x_{(2)}^{2}=1.6 ; 0.5>P>0.1$ \\
\hline $\begin{array}{l}\text { GENG } \\
\text { GESW }\end{array}$ & $\begin{array}{l}160 \\
194\end{array}$ & $\begin{array}{l}60 \\
52\end{array}$ & $\begin{array}{l}30 \\
66\end{array}$ & \}$x_{(2)}^{2}=10.5 ; \quad P<0.01$ \\
\hline $\begin{array}{l}\text { GESE } \\
\text { GESW }\end{array}$ & $\begin{array}{r}40 \\
194\end{array}$ & $\begin{array}{l}22 \\
52\end{array}$ & $\begin{array}{r}8 \\
66\end{array}$ & \}$x_{(2)}^{2}=9.4 ; \quad P<0.01$ \\
\hline
\end{tabular}

males resemble those of GESW, and GESE females are like GENC females. Thus the three sub-areas are related and form a distinct GE group. Within the GE area, not surprisingly, in view of the scale in space which is involved, the trend is towards high-spotted males to the south, and towards relatively high-spotted females in the south-west. Both these trends continue beyond the bounds of the GE area. Within it, however, males and females always retain their characteristic modes, that is a mode at 2 spots in the males and one at o spots in the females.

(e) The immediate periphery of the GE area

From these patterns it seems reasonable to present the GE area as a coherent unit wherein many important selection pressures are stabilised, 
probably to a greater degree than in southern England. The two southern sub-areas both tend to be adjusted in such a way that male spotting is higher while female spotting only just increases. An exaggeration of this trend would produce populations with very high male spotting and yet with the female mode at o spots retained; this situation is realised in the North African colonies.

It would hardly be expected, in view of the sources of the data being analysed here, that a clear picture could be obtained of zones of transition. Nevertheless, there are three populations on the periphery of the GE area which require particular consideration and which throw some light on what happens in regions lying between two stabilisation areas.

TABLE I3

Spot-distributions of M. jurtina samples from south-zeestern France

\begin{tabular}{|c|c|c|c|c|c|c|c|c|c|c|}
\hline & & \multicolumn{6}{|c|}{ Spots } & \multirow{2}{*}{ Total } & \multicolumn{2}{|c|}{ Spot-average } \\
\hline & & 0 & I & 2 & 3 & 4 & 5 & & 우 & o \\
\hline $\begin{array}{l}\text { Cauterets, Gavarnie, Luchon, } \\
\text { - -vii.o5, } \\
\text { St Jean-Pied-de-Port, } \\
\text { I 8.vi.36 }\end{array}$ & $\begin{array}{l}q \\
+ \\
0 \\
0 \\
+ \\
0 \\
0\end{array}$ & $\begin{array}{r}24 \\
1 \\
2 \\
\cdots\end{array}$ & $\begin{array}{r}21 \\
9 \\
1 \\
1\end{array}$ & $\begin{array}{r}19 \\
47 \\
1 \\
12\end{array}$ & $\begin{array}{r}2 \\
23 \\
1 \\
2\end{array}$ & $\begin{array}{r}\cdots \\
7 \\
\cdots \\
2\end{array}$ & $\begin{array}{l}\cdots \\
\mathrm{I} \\
\cdots \\
\cdots\end{array}$ & $\begin{array}{r}66 \\
88 \\
4 \\
17\end{array}$ & $\begin{array}{l}\mathrm{I} \cdot \mathrm{O} \\
(\mathrm{I} \cdot 2)\end{array}$ & $\begin{array}{l}2 \cdot 3 \\
2 \cdot 3\end{array}$ \\
\hline
\end{tabular}

(i) The Central Pyrenees, French side.-The south-western corner of France must be excluded from the GE area. Two samples are recorded in table I3; the I 936 sample is very small and could be consistent either with a continuation of high spotting in this area, or with a reversion to GESW.

The spot-distribution of the males from these collections is clearly in accord with the GESW pattern $\left(\mathrm{X}_{(3)}^{2}=4.9 ; 0.5>\mathrm{P}>0 . \mathrm{I}\right)$. The females, however, if compared with GESW samples, are heterogeneous $\left(\chi_{(2)}^{2}=\mathrm{I} 4.8 ; \mathrm{P}>0.00 \mathrm{I}\right)$. They do, in fact, approximate to a "flattop " distribution, that is, one in which the numbers at o spot, I spot and 2 spots are approximately equal. A few "flat-top" samples have been reported (Creed et al., I962) from the region of the GE-EG boundary and this is also the normal stabilisation of the three "large" islands of Scilly, St Mary's, St Martin's and Tresco.

(ii) Tarasp, East Switzerland.-This sample from central Europe is the only one to betray marked deviation from the GE pattern (table I4). It could be regarded as an instance of an isolated population responding to local selective influences which are markedly different from those in the surrounding stabilised colonies. One such has recently been found in the eastern half of southern England (Creed et al., in preparation). Another, in such a locality as the extremely isolated upper Inn valley, could reasonably be expected. 
Though the females are not significantly different from the GENC levels, their spot-average is nevertheless markedly lower and the mode at $o$ is of the order of 80 per cent. The males, on the other hand, are very significantly lower spotted than the GENC norm and $\chi_{(2)}^{2}=18 \cdot 1$; $\mathrm{P}>\mathrm{O} \cdot \mathrm{OO}$.

\section{TABLE 14}

Spot-distribution of a sample of M. jurtina from Tarasp, Engadine, East Switzerland

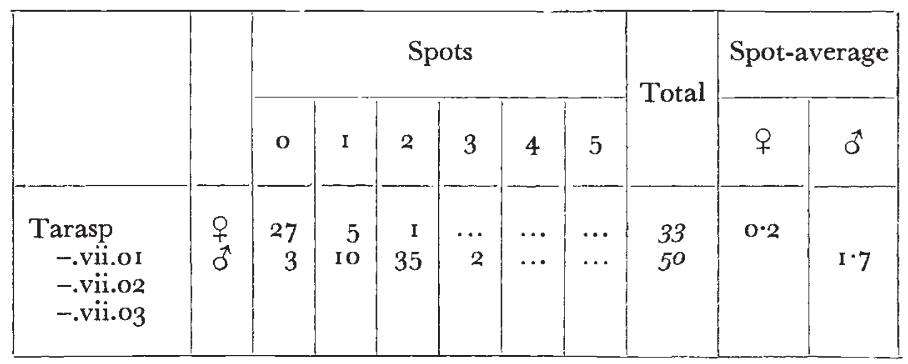

(iii) Macedonia.-One collection has so far been scored from the region of Macedonia and, although it seems to have been taken from several localities, it is predominantly representative of Thessaloniki (Salonika) and Mount Olympus. Although the sample is very small, there are signs that two different types of jurtina can be found within it. Since, also, no dates are attached, the position is even more obscure. However, the spot-values are strikingly different from those obtained from Bulgaria (GESE, at p. 192 above) and are suggestive of a transition to a higher spotted stabilisation.

TABLE I 5

Spot-distribution of a sample of $\mathbf{M}$. jurtina from Macedonia, mainly Thessaloniki and Mt Olympus

\begin{tabular}{|c|c|c|c|c|c|c|c|c|c|c|}
\hline & & \multicolumn{6}{|c|}{ Spots } & \multirow{2}{*}{ Total } & \multicolumn{2}{|c|}{ Spot-average } \\
\hline & & 0 & I & 2 & 3 & 4 & 5 & & 우 & $\hat{\sigma}$ \\
\hline $\begin{array}{l}\text { Macedonia } \\
\text { ? date }\end{array}$ & $\begin{array}{l}\text { q } \\
\text { ô }\end{array}$ & $\begin{array}{r}4 \\
\ldots\end{array}$ & $\begin{array}{r}7 \\
\ldots\end{array}$ & $\begin{array}{r}\cdots \\
3\end{array}$ & $\begin{array}{l}4 \\
4\end{array}$ & $\begin{array}{r}\ldots \\
2\end{array}$ & $\begin{array}{r}\ldots \\
2\end{array}$ & $\begin{array}{l}15 \\
I I\end{array}$ & I. 3 & $3 \cdot 3$ \\
\hline
\end{tabular}

The small sample from Macedonia (table I5) suggests, but of course this is not conclusive, that there could be a mode at I spot in the females. The sample is high-spotted in both sexes and is strongly divergent from the GESE pattern. The exact probability that the males are deviant is 0.016 ; the females could be homogeneous with $\mathrm{P}=0.644$; the combined probability that the samples are part of GESW just exceeds $0 \cdot 05$. 


\section{THE IBERIAN STABILISATION AREAS}

There is a sharp difference between GE and North Iberian jurtina. Towards the east the Pyrenees form the boundary between the GE and North Iberian stabilisations (see table I6), so that Vernet-les-Bains and

TABLE I6

Spot-distributions of samples of M. jurtina from the northern half of the Iberian peninsula, the $\mathcal{N} I B$ area

\begin{tabular}{|c|c|c|c|c|c|c|c|c|c|c|}
\hline & & \multicolumn{6}{|c|}{ Spots } & \multirow{2}{*}{ Total } & \multicolumn{2}{|c|}{ Spot-average } \\
\hline & & 0 & I & 2 & 3 & 4 & 5 & & 우 & $\widehat{0}$ \\
\hline $\begin{array}{l}\text { Catalonia, several sites, mainly } \\
\text { I } 929 \\
\text { San Ildefonso, nr. Madrid, } \\
\text { vi.viii.o6 } \\
\text { Sierra de Peña de Francia, nr. } \\
\text { Salamanca, v.vi.27-29 }\end{array}$ & $\begin{array}{l}0 \\
+ \\
0 \\
0 \\
+ \\
0 \\
0 \\
0 \\
0 \\
0\end{array}$ & $\begin{array}{r}12 \\
\ldots \\
39 \\
\ldots \\
2 \\
\cdots\end{array}$ & $\begin{array}{r}2 \\
\text { I } \\
\text { I I } \\
4 \\
2 \\
\cdots\end{array}$ & $\begin{array}{r}7 \\
16 \\
17 \\
16 \\
3 \\
1\end{array}$ & $\begin{array}{r}2 \\
12 \\
5 \\
9 \\
\dddot{6}\end{array}$ & $\begin{array}{r}\cdots \\
4 \\
\cdots \\
15 \\
\cdots \\
2\end{array}$ & $\begin{array}{l}\cdots \\
4 \\
\cdots \\
\cdots \\
\cdots\end{array}$ & $\begin{array}{r}23 \\
37 \\
72 \\
44 \\
7 \\
9\end{array}$ & $\begin{array}{c}\mathrm{I} \cdot 0 \\
0 \cdot 8 \\
(\mathrm{I} \cdot \mathrm{I})\end{array}$ & $\begin{array}{r}2 \cdot 8 \\
2 \cdot 84 \\
(3 \cdot 1)\end{array}$ \\
\hline
\end{tabular}

the Catalonian samples are strongly contrasted. In the central Pyrenees, on the other hand, we have evidence of an intermediate zone around Cauterets, Gavarnie and Luchon (Luz), and this is discussed on p. I98 above.

TABLE 17

Spot-distributions of samples of M. jurtina from the southern half of the Iberian peninsula. the SIB area

\begin{tabular}{|c|c|c|c|c|c|c|c|c|c|c|}
\hline & & \multicolumn{6}{|c|}{ Spots } & \multirow{2}{*}{ Total } & \multicolumn{2}{|c|}{ Spot-average } \\
\hline & & 0 & I & 2 & 3 & 4 & 5 & & 우 & $\sigma^{*}$ \\
\hline $\begin{array}{l}\text { Andalusia, several sites, } \\
\text { I920-29 } \\
\text { Ronda Valley, Andalusia, } \\
\text { vi.o6 } \\
\text { Southern Portugal,* } \\
\text { I920-29 } \\
\text { Alemtejo, southern Portugal, } \\
6 . v .27\end{array}$ & $\begin{array}{l}\text { q } \\
0 \\
0 \\
0 \\
0 \\
0 \\
0 \\
0 \\
+ \\
0 \\
0 \\
0 \\
0 \\
0 \\
0\end{array}$ & $\begin{array}{l}\text { I0 } \\
\cdots \\
4 \\
\cdots \\
\text { I } 9 \\
\cdots \\
34 \\
\cdots\end{array}$ & $\begin{array}{r}\mathrm{I} \\
\cdots \\
2 \\
\cdots \\
4 \\
\mathrm{I} \\
6 \\
\mathrm{I}\end{array}$ & $\begin{array}{r}2 \\
8 \\
2 \\
4 \\
3 \\
22 \\
7 \\
\ldots\end{array}$ & $\begin{array}{r}\cdots \\
2 \\
1 \\
6 \\
\cdots \\
27 \\
1 \\
5\end{array}$ & $\begin{aligned} \cdots \\
\text { I } \\
\cdots \\
\cdots \\
\cdots \\
9 \\
\cdots \\
2\end{aligned}$ & $\begin{array}{l}\cdots \\
\cdots \\
\cdots \\
\cdots \\
\cdots \\
5 \\
\cdots\end{array}$ & $\begin{array}{r}13 \\
11 \\
9 \\
10 \\
26 \\
64 \\
42 \\
8\end{array}$ & $\begin{array}{l}0.4 \\
(1 \cdot 0) \\
0.4 \\
0.5\end{array}$ & $\begin{array}{l}2 \cdot 4 \\
2 \cdot 8 \\
2 \cdot 8 \\
(3 \cdot 0)\end{array}$ \\
\hline
\end{tabular}

* From Cintra, near Lisbon, and the provinces of Alemtejo and Algarve.

That the North Iberian pattern continues southwards to the middle of the peninsula is suggested by the small sample obtained from Sierra de Peña de Francia. Further south, however, the spot-distributions change abruptly. Table I 7 records data from southern Portugal and southern Spain and it is clear that female spotting there is much lower with large modes at o spots. Yet the only large sample of males 
suggests that the level of spotting in this sex is similar to that of the North Iberian area.

This is the first occasion in which a conjunction between low-spotted females and high-spotted males has been found. McWhirter (I957) reported a high degree of correlation in British data between the levels of male and of female spotting. In the South Iberian area this breaks down and many North African populations are also characterised by a low-female-high-male type of spotting.

These limited data suggest that the Iberian peninsula is a region embracing populations which are transitional between the GESW pattern in France and the North African types.

\section{THE CENTRAL MEDITERRANEAN}

A series of samples are available from Central Italy, Sardinia, Sicily and Malta, G.C., covering the years I 896 to I927 (see table I8). The females within this region are highly variable, ranging from

TABLE I 8

Spot-distributions of M. jurtina samples from Central Italy, Sardinia, Sicily and Malta, G.C.

\begin{tabular}{|c|c|c|c|c|c|c|c|c|c|c|}
\hline & & \multicolumn{6}{|c|}{ Spots } & \multirow{2}{*}{ Total } & \multicolumn{2}{|c|}{ Spot-average } \\
\hline & & 0 & I & 2 & 3 & 4 & 5 & & $q$ & o \\
\hline $\begin{array}{l}\text { Roccaraso and Palena, I } 30 \mathrm{~km} \text {. } \\
\text { E. of Rome, end July early } \\
\text { August I } 907 \\
\text { Avellino and Paternopoli, } 80 \\
\text { km. E. of Naples, July I } 907 \\
\text { Monte Faito, nr. Salerno, } \\
\text { I goo-o9. } \\
\text { Sicily, mainly Palermo, } \\
\text { I922-27 } \\
\text { Sardinia, mainly Ogliastra (E. } \\
\text { coast), I goo-og } \\
\text { N.W. Sardinia, Sassari, } \\
\text { r896 } \\
\text { Malta, G.C., mainly v.02 }\end{array}$ & $\begin{array}{l}q \\
+ \\
0 \\
0 \\
+ \\
0 \\
0 \\
0 \\
0 \\
0 \\
0 \\
0 \\
0 \\
+ \\
0 \\
0 \\
0 \\
0 \\
0 \\
+ \\
0 \\
0\end{array}$ & $\begin{array}{r}\text { II } \\
\ldots \\
29 \\
\ldots \\
\text { II } \\
\ldots \\
56 \\
\ldots \\
67 \\
4 \\
\text { I } \\
\ldots \\
\text { II } \\
\ldots\end{array}$ & $\begin{array}{r}3 \\
\cdots \\
\text { I } 7 \\
\cdots \\
18 \\
\cdots \\
16 \\
2 \\
2 \\
14 \\
15 \\
1 \\
1 \\
1 \\
4 \\
\text { I }\end{array}$ & $\begin{array}{r}5 \\
2 \\
12 \\
43 \\
11 \\
9 \\
33 \\
12 \\
12 \\
64 \\
1 \\
3 \\
7 \\
7\end{array}$ & $\begin{array}{r}\cdots \\
\cdots \\
\text { I } \\
27 \\
4 \\
1 \\
8 \\
35 \\
2 \\
2 \\
42 \\
\cdots \\
3 \\
1\end{array}$ & $\begin{array}{r}\mathrm{I} \\
\ldots \\
\ldots \\
\ldots \\
\mathrm{I} 8 \\
\ldots \\
\mathrm{I} \\
3 \\
40 \\
\ldots \\
\mathrm{I} 7 \\
\ldots \\
2 \\
\ldots \\
4\end{array}$ & $\begin{array}{r}\ldots \\
\ldots \\
\ldots \\
\ldots \\
\text { I } \\
\ldots \\
\text { I } \\
\ldots \\
24 \\
\ldots \\
3 \\
\ldots \\
\ldots \\
\text { I } \\
2\end{array}$ & $\begin{array}{r}20 \\
2 \\
\\
59 \\
89 \\
44 \\
12 \\
116 \\
113 \\
95 \\
145 \\
3 \\
9 \\
24 \\
16\end{array}$ & $\begin{array}{c}0 \cdot 7 \\
I \cdot 2 \\
I \cdot I \\
0 \cdot 46 \\
(I \cdot 0) \\
I \cdot I\end{array}$ & $\begin{array}{l}2.5 \\
3.64 \\
2.43 \\
(2.7) \\
3.0\end{array}$ \\
\hline
\end{tabular}

samples similar to GESW, to others which resemble the North Iberian stabilisation; there is also one with a possibly significant mode at i spot. The males, however, where adequately sampled, are all high spotted with very variable modes. Thus the same trend as in Iberia is discernible, though here it is not possible to define any stabilisation areas.

\section{THE NORTH-WEST AFRICAN (NWA) STABILISATION AREA}

A considerable number of samples is available. Geographically the area covered stretches from the Atlantic coast of Morocco eastwards to the Algerian-Tunisian border. It is likely that the ecology of 
TABLE I9

Spot-distributions of $\mathrm{M}$. jurtina samples from the North-west African stabilisation area $(\mathcal{N W A})$

\begin{tabular}{|c|c|c|c|c|c|c|c|c|c|c|}
\hline & & & \multicolumn{5}{|c|}{ Spots } & \multirow{2}{*}{ Total } & \multicolumn{2}{|c|}{ Spot-average } \\
\hline & & o & I & 2 & 3 & 4 & 5 & & q & $\sigma^{*}$ \\
\hline \multicolumn{11}{|c|}{ (a) Easterly group from Ain Draham on Algerian-Tunisian border to Alger } \\
\hline $\begin{array}{l}\text { Ain Draham, I909, } \\
\text { I I -20.vii.. I } \\
\text { Bone, vi.84 } \\
\text { Khenchela, vi.o8 } \\
\text { Lambèse, vi.o7 } \\
\text { Yakouren, vii. and viii.o7 } \\
\text { El Biar, v.? } \\
\text { Hammam-mès-Koutime, } \\
\text { v.og, iv.I } 4 \\
\text { Djuradjura Mts., vi.84 } \\
\text { Djelfa, 8.vi.I } 3 \\
\text { Alger (Algiers), I9.v.08 } \\
\text { Hammam Rirha, 28.v.o8 }\end{array}$ & 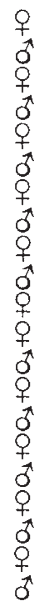 & $\begin{array}{r}\mathrm{I} 2 \\
\ldots \\
5 \\
\ldots \\
3 \\
\ldots \\
4 \\
\ldots \\
\mathrm{I} 3 \\
\ldots \\
\mathrm{I} 3 \\
7 \\
\mathrm{I} \\
3 \\
\ldots \\
2 \\
\cdots \\
6 \\
\ldots \\
\mathrm{1} 5 \\
\cdots\end{array}$ & $\begin{array}{r}2 \\
\ldots \\
\mathrm{I} \\
\ldots \\
\mathrm{I} \\
\ldots \\
\ldots \\
\ldots \\
6 \\
\mathrm{I} \\
3 \\
3 \\
\ldots \\
\mathrm{I} \\
\ldots \\
\mathrm{I} \\
\mathrm{I} \\
\mathrm{I} \\
\mathrm{I} \\
4 \\
3\end{array}$ & $\begin{array}{r}3 \\
\mathrm{I} \\
\mathrm{I} \\
\mathrm{I} \\
\mathrm{I} \\
3 \\
\ldots . \\
\ldots . \\
\cdots \\
\mathrm{I} \\
3 \\
3 \\
6 \\
2 \\
2 \\
\mathrm{I} \\
\mathrm{I} \\
2 \\
6 \\
6 \\
4 \\
\mathrm{I}\end{array}$ & $\begin{array}{r}\mathrm{I} \\
\ldots \\
\mathrm{I} \\
2 \\
\ldots \\
\ldots \\
\mathrm{I} \\
\mathrm{I} \\
\mathrm{I} \\
\ldots \\
2 \\
\ldots \\
\ldots \\
\mathrm{I} \\
5 \\
\ldots \\
\ldots \\
\ldots \\
3 \\
3 \\
\mathrm{I} \\
\mathrm{I} 6 \\
2 \\
\mathrm{I}\end{array}$ & $\begin{array}{r}\ldots \\
\text { I } \\
\ldots \\
2 \\
\ldots \\
2 \\
\ldots \\
2 \\
\ldots \\
2 \\
\ldots \\
\ldots \\
3 \\
\ldots \\
1 \\
\ldots \\
\ldots \\
\ldots \\
\ldots \\
\text { I0 } \\
\text { I } \\
\text { I } \\
\end{array}$ & $\begin{array}{r}\cdots \\
\ldots \\
\cdots \\
\text { I } \\
\ldots \\
2 \\
\ldots \\
\cdots \\
\cdots \\
\cdots \\
\cdots \\
\cdots \\
\text { I } \\
\cdots \\
\ldots \\
\cdots \\
\cdots \\
\cdots \\
\text { I } \\
\ldots \\
3\end{array}$ & $\begin{array}{r}16 \\
2 \\
8 \\
6 \\
5 \\
8 \\
5 \\
3 \\
19 \\
6 \\
19 \\
14 \\
16 \\
8 \\
3 \\
4 \\
5 \\
10 \\
34 \\
26 \\
39\end{array}$ & $\begin{array}{c}0.7 \\
(0.8) \\
(0.6) \\
(0.6) \\
0.3 \\
0.5 \\
0.9 \\
(0.8) \\
\ldots \\
0.8 \\
0.9\end{array}$ & $\begin{array}{c}\cdots \\
(3.5) \\
(3.4) \\
\cdots \\
(2.5)\end{array}$ \\
\hline \multicolumn{11}{|c|}{ (b) Westerly group from Oran area to Atlantic coast } \\
\hline $\begin{array}{l}\text { Oran (Masser mines), } \\
\text { I 7-I9.vi.I } 4 \\
\text { Oran, Grotte de Tabna,? } \\
\text { Saida, I 7.v. I } 3 \\
\text { South-west from Tabia, } \\
2 \text { I -30.vi.I } 5 \\
\text { Sebdou, I907, I 7.vi. I } 8 \\
\text { Taza,? } \\
\text { Atlas Mts., ? } \\
\text { Tangier, I o.vi.34 } \\
\text { Forest of Mamora (Ain Jorra), } \\
4-5 . v i .2 \text { I } \\
\text { Rabat, 2.v.25 } \\
\text { Ouled Farsch, } 2 \text { I -23.v.o I } \\
\text { Morocco, (several sites)? }\end{array}$ & 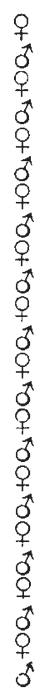 & $\begin{array}{r}\mathrm{I} 6 \\
\ldots \\
9 \\
\cdots \\
5 \\
\cdots \\
8 \\
\ldots \\
\mathrm{I} 6 \\
\mathrm{I} \\
\mathrm{I} 8 \\
\ldots \\
\mathrm{I} \\
\mathrm{I} \\
6 \\
\ldots \\
\mathrm{I} \\
\cdots \\
3 \\
\cdots \\
\cdots \\
\cdots \\
\mathrm{I} \\
\cdots \\
\cdots\end{array}$ & $\begin{array}{r}2 \\
3 \\
2 \\
\cdots \\
\mathrm{I} \\
\ldots \\
4 \\
\mathrm{I} \\
\mathrm{I} \\
\mathrm{I} \\
2 \\
\ldots \\
5 \\
\cdots \\
\mathrm{I} \\
\cdots \\
\mathrm{I} \\
\cdots \\
\cdots \\
\cdots \\
2 \\
\cdots \\
\mathrm{I} \\
\cdots\end{array}$ & $\begin{array}{r}5 \\
\text { I } 3 \\
5 \\
\text { I } 3 \\
\ldots \\
7 \\
6 \\
5 \\
6 \\
2 \\
1 \\
4 \\
5 \\
\text { I0 } \\
\text { I } \\
2 \\
2 \\
\cdots \\
2 \\
6 \\
\cdots \\
2 \\
7 \\
\text { I I }\end{array}$ & $\begin{array}{r}\text { I } \\
2 \text { I } \\
\ldots \\
\text { I I } \\
\ldots \\
6 \\
\ldots \\
9 \\
3 \\
9 \\
4 \\
3 \\
4 \\
7 \\
\text { I } \\
\ldots \\
\ldots \\
\text { I } \\
\ldots \\
\text { I } 2 \\
\ldots \\
3 \\
\ldots \\
9\end{array}$ & $\begin{array}{r}\ldots 8 \\
8 \\
\ldots \\
6 \\
\ldots \\
3 \\
\ldots \\
6 \\
1 \\
\text { I } 8 \\
\ldots \\
7 \\
\ldots \\
12 \\
\ldots \\
1 \\
\ldots \\
1 \\
\ldots \\
8 \\
\ldots \\
3 \\
\ldots \\
\text { I }\end{array}$ & $\begin{array}{r}\ldots \\
6 \\
\ldots \\
\ldots \\
\ldots \\
1 \\
\ldots \\
\ldots \\
\ldots \\
7 \\
\ldots \\
1 \\
\ldots \\
3 \\
\ldots \\
\ldots \\
\ldots \\
\ldots \\
\ldots \\
2 \\
\ldots \\
2 \\
\ldots \\
2\end{array}$ & $\begin{array}{r}24 \\
51 \\
16 \\
30 \\
6 \\
17 \\
18 \\
21 \\
27 \\
38 \\
25 \\
15 \\
25 \\
33 \\
9 \\
3 \\
4 \\
2 \\
5 \\
28 \\
2 \\
10 \\
19 \\
32\end{array}$ & $\begin{array}{l}0 \cdot 6 \\
0 \cdot 8 \\
(0 \cdot 2) \\
0 \cdot 9 \\
I \cdot 0 \\
0 \cdot 6 \\
I \cdot I \\
(0 \cdot 7) \\
\ldots \\
(0 \cdot 8)\end{array}$ & $\begin{array}{l}3.0 \\
2.8 \\
2.9 \\
3.0 \\
3.7 \\
3.3 \\
3.2 \\
\ldots \\
\ldots \\
3.2 \\
3.5 \\
3.1\end{array}$ \\
\hline \multicolumn{11}{|c|}{ (c) Possible higher-spotted enclave in part of Atlas range } \\
\hline $\begin{array}{l}\text { Azrou, vii.2 I } \\
\text { Timhadit, I } 924 \\
\text { Zemmours, end v.2 I }\end{array}$ & $\begin{array}{l}q \\
0 \\
q \\
0 \\
0 \\
0 \\
0 \\
\sigma\end{array}$ & $\begin{array}{c}\text { I } \\
\text { I } \\
\ldots \\
\cdots \\
\cdots\end{array}$ & $\begin{array}{r}\text { I } \\
\ldots \\
\ldots \\
3 \\
\ldots\end{array}$ & $\begin{array}{r}5 \\
\ldots \\
\ldots \\
\text { I } \\
\ldots\end{array}$ & $\begin{array}{r}2 \\
4 \\
\mathrm{I} \\
2 \\
\ldots\end{array}$ & $\begin{array}{c}\ldots \\
\ldots \\
3 \\
\ldots \\
\ldots\end{array}$ & $\begin{array}{r}\ldots \\
\ldots \\
3 \\
\ldots \\
2\end{array}$ & $\begin{array}{l}9 \\
5 \\
7 \\
6 \\
2\end{array}$ & $\begin{array}{l}(\mathrm{I} \cdot 9) \\
(3 \cdot 1) \\
(\mathrm{I} \cdot 8)\end{array}$ & $(4 \cdot 3)$ \\
\hline
\end{tabular}


North-West African jurtina will differ from that of the GE insects. The appearance of the imagines is brighter and their size larger. Emergence seems often to begin in April and is certainly well established in May. Without a detailed study of the habitat it is difficult to estimate to what extent the insect is divided into colonies, but, since the samples are often derived from the coastal areas, higher mountainous regions or from watercourses, there should be much less gene-flow across the area than would be the case in a more temperate and damper climate.

TABLE 20

Combined percentage spot-numbers of (a) eastern (b) western and (c) " Atlas enclave" groups of $\mathrm{M}$. jurtina in the $\mathcal{N W A}$ area

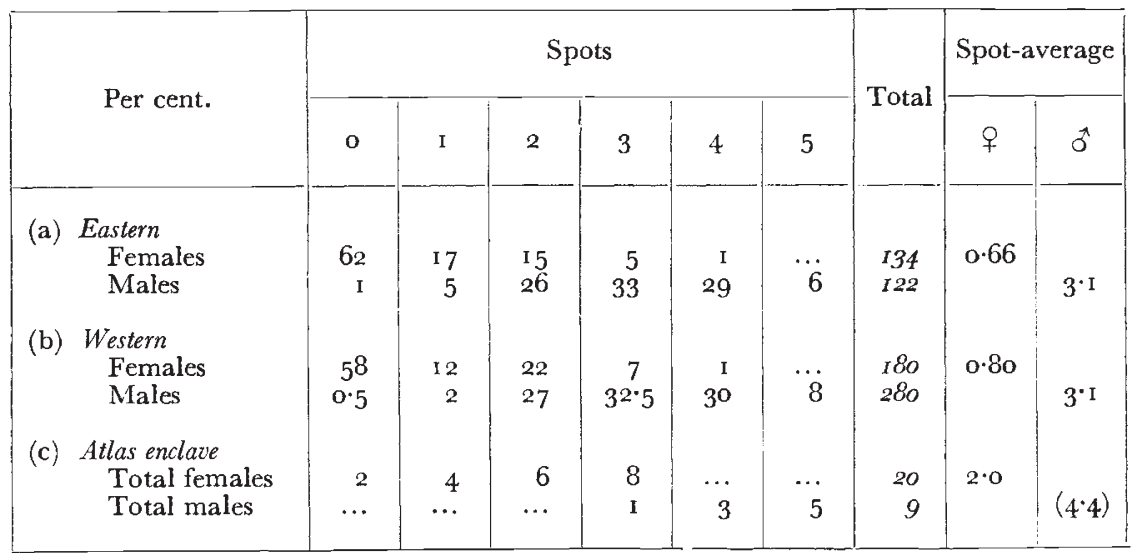

If this view is correct, it is all the more remarkable that the NorthWest African area is very strongly stabilised. Females retain the familiar major mode at o spots; there is usually an indication of a minor mode at 2 spots and this is indisputable in the western half of the region from the Atlantic to Oran. Males right across the area exhibit very high spotting with a distribution in which specimens at 2, 3 and 4 spots are often roughly equal. Specimens at 5 spots are commoner than ones with less than 2.

Within the North-West African area there is possibly a small enclave with even higher spotting. Three small samples were obtained at Azrou, Timhadit and Zemmours in the Moroccan Atlas. The females total only 2o, of which, however, 8 are at 3 spots and 6 are at 2 . Males are available only from Timhadit and Zemmours, but these consist of 5 at 5 spots, 3 at 4 spots and I at 3 spots. The spot-averages can thus be estimated as $2 \cdot 0$ for the females and 4.4 for the males. These levels exceed $0 \cdot 7-0 \cdot 8$ for females and $3 \cdot 1$ for males which are characteristic of the rest of the North-West African area.

\section{THE CANARY ISLANDS}

These are the outlying south-westerly habitat of $M$. jurtina. The imagines are large and bright and emergence begins in April. There 
are no data suggesting anything other than a univoltine cycle. Specimens studied hail from some four or five islands and go back to I89o. Accordingly no idea can be obtained of what differences, if any, there may be between islands; table 2 I can do no more than give a rough sketch of the overall situation in the archipelago.

TABLE 2I

Spot-distributions of M. jurtina specimens collected in the Canary Islands, 1890-1913

\begin{tabular}{|c|c|c|c|c|c|c|c|c|c|c|}
\hline & & \multicolumn{6}{|c|}{ Spots } & \multirow{2}{*}{ Total } & \multicolumn{2}{|c|}{ Spot-average } \\
\hline & & o & I & 2 & 3 & 4 & 5 & & q & 0 \\
\hline $\begin{array}{l}\text { I } 890-1913 \\
\text { Canary Islands }\end{array}$ & $\begin{array}{l}\text { p } \\
0 \\
0\end{array}$ & $\begin{array}{l}9 \\
\mathrm{I}\end{array}$ & $\begin{array}{c}5 \\
\cdots\end{array}$ & $\begin{array}{l}7 \\
9\end{array}$ & $\begin{array}{l}\text { I } \\
7\end{array}$ & $\begin{array}{r}\ldots \\
3\end{array}$ & $\begin{array}{l}\ldots \\
\cdots\end{array}$ & $\begin{array}{l}22 \\
20\end{array}$ & $1 \cdot 0$ & $2 \cdot 6$ \\
\hline
\end{tabular}

The sample suggests $(a)$ some similarity to the North Iberian pattern and $(b)$ considerable deviation from the nearby African coast where female spotting is lower and male spotting higher.

Spot-placing in the Canaries, however, is entirely costally biased and hence differs both from the Iberian and the African stabilisations. There is thus a curious resemblance to the situation in the Isles of Scilly, reinforced by the occurrence of double eyes and extra spots on the forewing - a feature of many Scillonian populations.

\section{THE WEST ASIAN REGION (WA)}

The samples from Turkey, Syria, Azerbaijan, Iraq and Iran do not suggest strong stabilisation. The general appearance of the

TABLE 22

Spot-distributions of M. jurtina samples from the northerly portion of the West Asian region $(W A N)$

\begin{tabular}{|c|c|c|c|c|c|c|c|c|c|c|}
\hline & & \multicolumn{6}{|c|}{ Spots } & \multirow{2}{*}{ Total } & \multicolumn{2}{|c|}{ Spot-average } \\
\hline & & o & I & 2 & 3 & 4 & 5 & & 우 & 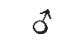 \\
\hline \multirow{8}{*}{$\begin{array}{l}\text { Brusa, Turkey, vii.92 } \\
\text { Kedos, ı.vi.92 } \\
\text { Tokat, Turkey, I } 906 \\
\text { Elisavetpol (Kirovabad), Azer- } \\
\text { baijan, vi. Io } \\
\text { Persia, inc. Elburz Mts., vi.31 }\end{array}$} & 우 & I 2 & 5 & 4 & 4 & $\ldots$ & $\ldots$ & 25 & $I \cdot O$ & \multirow[b]{2}{*}{$(2 \cdot 4)$} \\
\hline & ổ & $\ddot{8}$ & $\cdots$ & 6 & $\begin{array}{r}2 \\
\ldots\end{array}$ & $\begin{array}{r}\text { I } \\
\ldots\end{array}$ & $\ldots$ & $\begin{array}{r}9 \\
16\end{array}$ & \multirow{2}{*}{0.6} & \\
\hline & $0^{x}$ & $\ldots$ & $\ldots$ & 2 & 2 & 1 & I & 6 & & $(3 \cdot 2)$ \\
\hline & $\begin{array}{l}0 \\
+1 \\
1\end{array}$ & 3 & $\cdots$ & $\cdots$ & $\cdots$ & $\cdots$ & $\cdots$ & 3 & \multirow{3}{*}{$\begin{array}{c}\ldots \\
(0 \cdot 1)\end{array}$} & $(0,0)$ \\
\hline & $\begin{array}{l}\text { o } \\
\text { O }\end{array}$ & $\dddot{6}$ & $\begin{array}{r}\cdots \\
I\end{array}$ & $\begin{array}{r}\text { I } \\
\ldots .\end{array}$ & $\begin{array}{r}5 \\
\ldots\end{array}$ & $\begin{array}{r}2 \\
\ldots\end{array}$ & $\begin{array}{c}\mathrm{I}^{*} \\
\ldots\end{array}$ & $\begin{array}{l}9 \\
7\end{array}$ & & $(3 \cdot 4)$ \\
\hline & $\hat{0}$ & $\ldots$ & $\ldots$ & 4 & 2 & 2 & $\ldots$ & 8 & & $(2 \cdot 75)$ \\
\hline & 우 & I3 & 3 & 2 & $\cdots$ & $\cdots$ & $\cdots$ & 18 & $0 \cdot 4$ & \\
\hline & \% & $\cdots$ & $\cdots$ & I9 & 9 & $\cdots$ & $\cdots$ & 28 & & $2 \cdot 3$ \\
\hline
\end{tabular}


imagines differs markedly from site to site and as far as spot-distributions are concerned only a few definitions can be put forward. The females are low-spotted with modes at o spots; male spotting is very variable. In general, the northern half of the area shows a tendency to higher spotting (WAN) and the southern half is much less spotted (WAS)-approximating to the Irish situation.

TABLE 23

Spot-distributions of M. jurtina samples from the southerly portion of the West Asian region $(W A S)$

\begin{tabular}{|c|c|c|c|c|c|c|c|c|c|c|}
\hline & & \multicolumn{6}{|c|}{ Spots } & \multirow{2}{*}{ Total } & \multicolumn{2}{|c|}{ Spot-average } \\
\hline & & 0 & I & 2 & 3 & 4 & 5 & & 우 & 0 \\
\hline $\begin{array}{l}\text { Meidan Ekbès, Syria, I890-9 I } \\
\text { Syria,? } \\
\text { Salahuddin, Kurdistan, } \\
\text { 3-Io.vi.57* }\end{array}$ & $\begin{array}{l}q \\
+ \\
0 \\
+ \\
+ \\
0 \\
0 \\
+ \\
0 \\
0\end{array}$ & $\begin{array}{r}\text { I } 5 \\
5 \\
\text { I } 7 \\
9 \\
10 \\
6\end{array}$ & $\begin{array}{r}\text { I } \\
3 \\
\text { I } \\
\text { I I } \\
\ldots \\
5\end{array}$ & $\begin{array}{r}\mathrm{I} \\
2 \mathrm{I} \\
\ldots \\
32 \\
\mathrm{I} \\
2\end{array}$ & $\begin{array}{r}\ldots \\
7 \\
\ldots \\
5 \\
\ldots \\
3\end{array}$ & $\begin{array}{r}\ldots \\
4 \\
\ldots \\
\ldots \\
\ldots \\
2\end{array}$ & $\begin{array}{c}\ldots \\
\cdots \\
\cdots \\
2 \\
\ldots \\
I\end{array}$ & $\begin{array}{l}17 \\
40 \\
18 \\
59 \\
11 \\
19\end{array}$ & $\begin{array}{c}0.2 \\
\ldots\end{array}$ & $\begin{array}{l}2 \cdot 05 \\
I \cdot 7 \\
I \cdot 6\end{array}$ \\
\hline
\end{tabular}

* This sample due to L. G. Higgins is included despite its late date as an indication of a possible stabilisation area.

It will be clear from a comparison of tables 22 and 23 that no definite boundary has been found between the GESE and West Asian (North) areas. The sample from Brusa could well be incorporated into GESE, but eastwards male spot-levels tend to rise. Partly wedged between GESE and West Asia (North) are divergent Macedonian samples (see p. 199). Only a detailed study could fill in the picture in this rather complicated area, where divergences in the general appearance of the imagines become so marked that there must always be some doubt as to the exact limits of the species jurtina.

\section{TRANS-SPECIFICITY OF SPOT-DISTRIBUTION}

In two cases it appears that specimens from the West Asian region which have been assigned to other species have similar spot-distributions to those of nearby colonies of $M$. jurtina.

(a) Table 24 gives details of the spot-numbers in samples of M. telmessia (Zeller); one is from Beirut, the Lebanon, dated I898, 1908 and 1916, and the other is from scattered localities in West Asia.

$M$. telmessia from Beirut shows identical spotting with $M$. jurtina from Syria; the homogeneity of the male spot-distribution is measured by $\chi_{(3)}^{2}=1 \cdot 49 ; 0{ }^{\circ}>\mathrm{P}>0 \cdot 5$. Furthermore, the placing of the spots in $M$. telmessia exhibits patterns similar to those known in jurtina.

(b) The Cypriot race has been assigned to a species cypricola (Graves). One respect in which it is deviant is that some specimens o 2 
have white spots on the undersurface of the hind-wings. Counting only black spots, however, the distribution is even more extremely lowspotted than that found in the West Asian (South) group. Two samples

TABLE 24

Spotting of M. telmessia (Zeller)

\begin{tabular}{|c|c|c|c|c|c|c|c|c|c|c|}
\hline & & \multicolumn{6}{|c|}{ Spots } & \multirow{2}{*}{ Total } & \multicolumn{2}{|c|}{ Spot-average } \\
\hline & & 0 & I & 2 & 3 & 4 & 5 & & 우 & $\hat{0}$ \\
\hline $\begin{array}{l}\text { Beirut, The Lebanon, } \\
\text { I } 898 \text {, I908, I9I6 } \\
\text { West Asian localities, } \\
\text { ? dates }\end{array}$ & 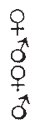 & $\begin{array}{r}\text { I5 } \\
\text { I0 } \\
7 \\
3\end{array}$ & $\begin{array}{l}\cdots \\
9 \\
3 \\
\text { I }\end{array}$ & $\begin{array}{r}21 \\
3 \\
8\end{array}$ & $\begin{array}{l}\cdots \\
6 \\
I \\
5\end{array}$ & $\begin{array}{l}\cdots \\
\cdots \\
\cdots \\
\cdots\end{array}$ & $\begin{array}{l}\cdots \\
2 \\
\cdots \\
\cdots\end{array}$ & $\begin{array}{l}15 \\
48 \\
14 \\
17\end{array}$ & $\begin{array}{l}\text { nil } \\
0 \cdot 9\end{array}$ & $\begin{array}{l}\mathrm{I} \cdot 64 \\
\mathrm{I} \cdot 9\end{array}$ \\
\hline
\end{tabular}

are recorded in table 25. The general appearance of the imagines is very different from the Mainland pattern.

TABLE 25

Spot-distributions (black spots only) of M. cypricola (Graves)

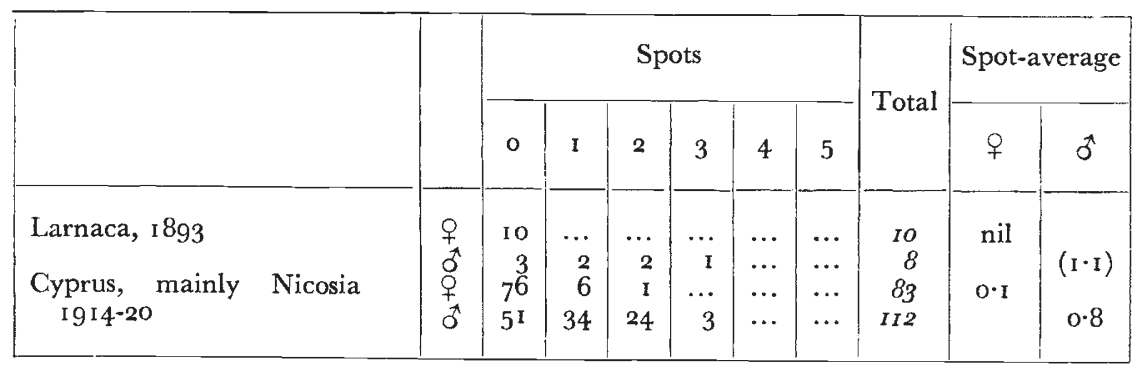

\section{DISCUSSION}

The picture which emerges from a study of samples of Maniola jurtina taken throughout Europe, West Asia and North Africa and covering a span of roughly 60 years is of a series of stabilisations, each clearly defined in terms of spot-distribution. As is only to be expected from museum material, the geographical distinction between these remains somewhat imprecise and a great many more data would be required in order to determine the circumstances in which one form of spot-stabilisation changes into another. In a wide southern belt on both sides of the Mediterranean, spotting appears to have been stabilised at levels quite unlike those of the greater part of Europe. Our knowledge of the processes of selection and the agents involved in them is still limited; it is not impossible that the spot-distributions of distinct colonies within the same stabilisation area are being maintained by a variety of selective agents operating at particular phases of the life-cycle of the insect (McWhirter, in preparation). 
The examination of samples which cover the greater part of the insect's total geographical range has revealed an interesting situation. While the insect at the centre of its range (that is the General European area) exhibits remarkable stability, it tends to show greater variability towards its periphery. Thus in the outlying populations in Ireland, the Isles of Scilly, the Canary Islands, North Africa and the three peninsulas of Iberia, Italy and Greece, and in the West Asian region, we find a number of different stabilisations, each limited to geographical areas which are small compared with the very large GE zone. We would expect to find that in specialised environments near the periphery, adjustment and survival of the colonies are only possible if what are elsewhere unusual genetic combinations are called into play from the gene-pool. It seems likely that further adaptability could be achieved by adopting intra-seasonal variations; in fact, we already see that these occur in some, at least, of the peripheral populations, (e.g. in the Isles of Scilly (Creed et al., in preparation), southern England, and possibly in Italy and Sicily); there is no sign of intra-seasonal shift in the main body of the GE stabilisations.

The levels in corresponding samples of female and male spotting were found by McWhirter (1957) to be strongly correlated in British populations examined up to I955. Evidently this correlation extends throughout the GE stabilisation area but breaks down outside it, though it could still be valid in West Asia. In South Iberia and North-West Africa, females are usually low spotted yet the males contribute some of the most highly spotted samples we have seen. It seems as though the sex limitation of the expression of the spot-genes is achieved in some quite different way in these southerly stabilisation areas. Since very strong selection pressures are known to operate on pre-imaginal characters which are influenced by spot-genes, in England and in the Isles of Scilly (Dowdeswell, I96o, I96r; McWhirter, in preparation), and these affect either one sex, or the other, or both, in different localities, it is quite reasonable to suppose that jurtina in its southern habitats has adjusted itself to very different kinds of selection from those exerted in Britain.

Patterns of spotting on the fore- and hind-wings similar to those found in $M$. jurtina are a universal characteristic of the family Satyridæ and appear in several other butterfly families. This underlines the importance of the particular gene systems involved. They may be far more significant than the other characters traditionally used as criteria for assessing species. We have seen how the West Asian (South) spotdistribution is evident both in $M$. jurtina in that region and in $M$. telmessia; M. cypricola in Cyprus, if indeed it merits specific rank, could offer another illustration of the same principle. The genes controlling spotting appear, in other words, to be trans-specific, trans-generic, trans-familial and therefore of great antiquity.

The gene-systems influencing spotting must have been established far longer than have the genera and species now existing. It follows 
that many other interacting genes in the Satyrine gene-complex must have long been selected and evolved against the background provided by those controlling spotting. Although no mathematical model has yet been evolved to explain this, it seems that very ancient genes (palaeogenes) tend to maintain themselves in freely breeding populations at certain frequencies. When eventually these frequencies change, as a result of prolonged and violent alteration in selection, they do so in relatively large quantum steps; these are detectable through the characters which the palaeogenes control.

\section{SUMMARY}

I. Spot-distributions in the Meadow Brown Butterfly (Maniola jurtina L.) are stabilised at not less than three different levels in the British Isles. In addition, a number of peripheral stabilisations exist in the south-west, especially in the Isles of Scilly.

2. Museum collections show that the present pattern in Britain extends back at least to 1920 .

3. European data for the years I890-1935 obtained from the British Museum collections show that the South English spot-distribution extends at least to Finland, Bulgaria and southern France, forming a "General European" (GE) stabilisation area.

4. Round the periphery there is a number of different stabilisations, for instance in North and South Iberia, North-West Africa and West Asia.

5. In the Pyrenean region the transition between the GE and North Iberian stabilisations has been studied.

6. The spot-distribution of $M$. jurtina in the West Asian area is concurrent with those of M. cypricola (Graves) and M. telmessia (Zeller). Thus the incidence of spotting overrides the current speciation in Maniola. All Satyrines bear evidence of the action of genes with comparable phenotypic effects and some other families of butterflies probably do so too. Such trans-familial and trans-generic genesystems are likely to be of great antiquity.

Acknoweledgments. - We are indebted to Mr L. Goodson of the Tring Museum and to Mr T. G. Howarth and Mr M. P. Clifton of the British Museum (Natural History) for allowing us to inspect collections of Maniola spp. and for generous help and interest. Professor E. B. Ford, F.R.S., the Hon. Miriam Rothschild and Dr E. R. Creed have offered valuable advice and criticism. One of us (W. H. D.) gratefully acknowledges the loan of a calculating machine by the Royal Society.

Many of the data recorded here are due to Walter, Second Baron Rothschild, who collected more specimens of Lepidoptera than any other lepidopterist. His belief that species should be defined on a wide basis, not on a few " type" specimens, made this analysis possible.

\section{REFERENCES}

CREED, E. R., DOWDESWELI, W. H., FORD, E. B., AND MCWHIRTER, K. G. I959. Evolutionary studies on Maniola jurtina: The English mainland, I956-1957. Heredity, I3, 363-39 . 
CREED, E. R., DOWDESWELL, W. H., FORD, E. B., AND MCWHIRTER, K. G. 1962. Evolutionary studies on Maniola jurtina: the English mainland, 1958-196o. Heredity, $I 7,237-265$.

CREED, E. R., FORD, E. B., AND MCWHIRTER, K. G. 1964. Evolutionary studies on Maniola jurtina: the Isles of Scilly, 1958-1959. Heredity, I9, 471-488.

DowDEswell, W. H. 1961. Experimental studies on natural selection in the butterfly, Maniola jurtina. Heredity, $I 6,39-52$.

DOWDESWELL, w. H. 1962. A further study of the butterfly Maniola jurtina in relation to natural selection by Apanteles tetricus. Heredity, I7, 513-523.

DOWDESWELL, W. H., AND FORD, E. B. 1953. The influence of isolation on variability in the butterfly Maniola jurtina L. Symposia Soc. Exp. Biol., 7, 254-273.

DOWDESWELL, W. H., AND FORD, E. B. 1955. Ecological genetics of Maniola jurtina L. on the Isles of Scilly. Heredity, 9, 265-272.

FORD, E. B. 1964. Ecological Genetics. Methuen, London.

FORMAN, B., FORD, E. B., AND MCWHIRTER, K. G. 1959. An evolutionary study of the butterfly Maniola jurtina in the north of Scotland. Heredity, I3, 353-36r.

MCWHIRTER, K. G. 1957. A further analysis of variability in Maniola jurtina L. Heredity, $I I, 359-37$ I.

\section{GAZETTEER}

Place

1. Ain Draham, Tunisia

2. Akbes, ? Meidan Ekbes, Syria

3. Alemtejo, South Portugal

4. Algarve, South Portugal

5. Alger (Algiers)

6. Avellino, Italy

7. Azrou, Morocco

8. Bad Reinerz, Silesia

9. Bad Wörishofen, Bavaria

ı. Baile Herculane, Romania(Herkulesfürdö; Herkulesbad)

I1. Bone, Algeria

12. Brno, Czechoslovakia, (Brünn)

13. Brusa (Bursa, Prusa), Turkey

14. Cauterets, France

15. Château d'Oex, Vaud, Switzerland

I6. Cintra, Lisbon, Portugal

17. Csehtelek (nr. Oradea Mare, q.v.)

18. Digne, Basses Alpes, France

19. Djelfa, Algeria

20. Djuradjura Mts

21. El Biar

22. Elburz Mts, Iran

23. Elisavetpol (Kirovabad), Azerbaijan

24. Gavarnie, France

25. Grotte de Tabna, Oran, Algeria

26. Hammam Rirha, Algeria

27. Hammam-mès-Koutime, ? Algeria

28. Hannover, Germany

29. Het Zoute, Belgium

3o. Inga (Ingö, Inkoo), Finland

31. Kaposvar, Hungary

32. Kedos, Asia Minor

33. Khenchela, Constantine, Algeria

\begin{tabular}{|c|c|c|}
\hline \multicolumn{2}{|c|}{ Co-ordinates } & Stabilisat \\
\hline $36^{\circ} 48^{\prime} \mathrm{N}$ & $08^{\circ} 40^{\prime} \mathrm{E}$ & NWA \\
\hline $36^{\circ} 48^{\prime} \mathrm{N}$ & $36^{\circ} 4 \mathrm{I}^{\prime} \mathrm{E}$ & WAS \\
\hline - & - & SIB \\
\hline - & 一 & SIB \\
\hline${ }^{\circ} 50^{\prime} \mathrm{N}$ & $03^{\circ} \mathrm{Oo}^{\prime} \mathrm{E}$ & NWA \\
\hline${ }^{\circ} 54^{\prime} \mathrm{N}$ & $14^{\circ} 47^{\prime} \mathrm{E}$ & CM \\
\hline $3^{\circ} 27^{\prime} \mathrm{N}$ & $05^{\circ} 14^{\prime} \mathrm{W}$ & Atlas \\
\hline${ }^{\circ} 23^{\prime} \mathrm{N}$ & $16^{\circ} 23^{\prime} \mathrm{E}$ & GENC \\
\hline $3^{\circ} 00^{\prime} \mathrm{N}$ & $10^{\circ} 35^{\prime} \mathrm{E}$ & GENC \\
\hline${ }^{\circ} 53^{\prime} \mathrm{N}$ & $22^{\circ} 27^{\prime} \mathrm{E}$ & GENC \\
\hline${ }^{\circ} 55^{\prime} \mathrm{N}$ & $07^{\circ} 44^{\prime} \mathrm{E}$ & NWA \\
\hline${ }^{\circ} 12^{\prime} \mathrm{N}$ & $16^{\circ} 37^{\prime} \mathrm{E}$ & GENC \\
\hline${ }^{\circ} 12^{\prime} \mathrm{N}$ & $29^{\circ} \mathrm{O} 4^{\prime} \mathrm{E}$ & WAN \\
\hline $53^{\prime} \mathrm{N}$ & $00^{\circ} 06^{\prime} \mathrm{W}$ & Pyrenee \\
\hline${ }^{\circ} 28^{\prime} \mathrm{N}$ & $07^{\circ} 08^{\prime} \mathrm{E}$ & GESW \\
\hline $3^{\circ} 48^{\prime} \mathrm{N}$ & $09^{\circ} 23^{\prime} \mathrm{W}$ & SIB \\
\hline${ }^{\circ} 05^{\prime} \mathrm{N}$ & $06^{\circ} 14^{\prime} \mathrm{E}$ & GESW \\
\hline${ }^{\circ} 43^{\prime} \mathrm{N}$ & $03^{\circ} 14^{\prime} \mathrm{E}$ & NWA \\
\hline o km. e & ast of Alger & NWA \\
\hline ? & $?$ & NWA \\
\hline${ }^{\circ} 00^{\prime} \mathrm{N}$ & $52^{\circ} \mathrm{Oo}^{\prime} \mathrm{E}$ & WAN \\
\hline${ }^{\circ} 43^{\prime} \mathrm{N}$ & $46^{\circ} 20^{\prime} \mathrm{E}$ & WAN \\
\hline${ }^{\circ} 44^{\prime} \mathrm{N}$ & $\mathrm{OO}^{\circ} \mathrm{Or}^{\prime} \mathrm{W}$ & Pyrenee \\
\hline & ? & NWA \\
\hline $26^{\prime} \mathrm{N}$ & $\mathrm{O} 2{ }^{\circ} 28^{\prime} \mathrm{E}$ & NWA \\
\hline ? & ? & NWA \\
\hline${ }^{\circ} 23^{\prime} \mathrm{N}$ & $\mathrm{og}^{\circ} 44^{\prime} \mathrm{E}$ & GENC \\
\hline${ }^{\circ} 2 I^{\prime} N$ & $03^{\circ} 19^{\prime} \mathrm{E}$ & GENC? \\
\hline${ }^{\circ} \mathrm{O}^{\prime} \mathrm{N}$ & $24^{\circ} \mathrm{OI}^{\prime} \mathrm{E}$ & GENG \\
\hline${ }^{\circ} 2 I^{\prime} N$ & $\mathrm{I} 7^{\circ} 49^{\prime} \mathrm{E}$ & GENC \\
\hline 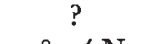 & & WA \\
\hline 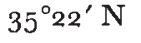 & & Nh \\
\hline
\end{tabular}

Stabilisation

WAS

SIB

NWA

CM

GENC

GENC

GENG

GENG

AN

GESW

GESW

NWA

WAN

Pyrenees

NWA

NWA

GENC

GENC?

GENC

NWA 


Place
34. Lahr-in-Baden, Germany
35. Lambèse, Algeria
36. Larnaca, Cyprus
37. Liège, Belgium
38. Luchon (Luz), France
39. Mamora, Forest of, Rabat, Morocco
40. Masser Mines, Oran, Algeria
41. Meidan Ekbes, Syria
42. Meissen, nr. Dresden, Saxony
43. Mödling, nr. Vienna
44. Monte Faito, Salerno, Italy
45. Nicosia, Cyprus
46. Ogliastra, Sardinia
47. Olympus, Mt.
48. Oradea Mare (Nagy Varad), Romania
49. Oran, Algeria
50. Ouled Farsch

51. Palena, Italy

52. Palermo, Sicily

53. Paternopoli, Italy

54. Pravadiya, Bulgaria

55. Rabat, Morocco

56. Rennes, Brittany, France

57. Roccaraso, Italy

58. Ronda Valley, Andalusia, Spain

59. Royan, Charente Inférieure, France

6o. Saida, Oran, Algeria

6r. St Jean-de-Monts, Vendée, France

62. St Jean-Pied-de-Port, France

63. St Martin-Vésubie, Alpes Maritimes, France

64. Salahuddin, Kurdistan, Iraq

65. Salzdetfurth, Hannover, Germany

66. San Ildefonso, Segovia, Spain

67. Sassari, Sardinia

68. Sebdou, Oran, Algeria

69. Senj (Zengg), Croatia, Yugoslavia

7o. Sierra de Peña de Francia, Salamanca, Spain

71. Sofia, Bulgaria

72. Tabia, Oran, Algeria

73. Tangier

74. Tarasp, Engadine, Switzerland

75. Taza, Morocco

76. Thessaloniki (Salonika), Greece

77. Timhadit, Morocco

78. Tokat, Turkey

79. Vernet-les-Bains, E. Pyrenees, France

8o. Vitosh, Mt, Bulgaria

81. Yakouren, Algeria

82. Zemmours, Morocco

\begin{tabular}{|c|c|c|}
\hline \multicolumn{2}{|c|}{ Co-ordinates } & Stabilisation \\
\hline $4^{8^{\circ}} 2 I^{\prime} N$ & $07^{\circ} 52^{\prime} \mathrm{E}$ & GENC \\
\hline $35^{\circ} 3^{\prime} \mathrm{N}$ & $06^{\circ} 15^{\prime} \mathrm{E}$ & NWA \\
\hline $34^{\circ} 55^{\prime} \mathrm{N}$ & $33^{\circ} 39^{\prime} \mathrm{E}$ & - \\
\hline $50^{\circ} 3^{8^{\prime} N}$ & $05^{\circ} 35^{\prime} \mathrm{E}$ & GENC? \\
\hline $42^{\circ} 52^{\prime} \mathrm{N}$ & $\mathrm{Oo}^{\circ} \mathrm{Oo}^{\prime}$ & Pyrenees \\
\hline $34^{\circ} \mathrm{O}^{\prime} \mathrm{N}$ & $\mathrm{o6}^{\circ} 3 \mathrm{o}^{\prime} \mathrm{W}$ & NWA \\
\hline & $?$ & NWA \\
\hline $36^{\circ} 4^{8^{\prime} \mathrm{N}}$ & $3^{6^{\circ}} 4^{I^{\prime}} \mathrm{E}$ & WAS \\
\hline $5^{\circ}{ }^{\circ} 9^{\prime} \mathrm{N}$ & $13^{\circ} 28^{\prime} \mathrm{E}$ & GENC \\
\hline $4^{8^{\circ}} 05^{\prime} \mathrm{N}$ & $16^{\circ} 18^{\prime} \mathrm{E}$ & GENC \\
\hline $40^{\circ} 40^{\prime} \mathrm{N}$ & $14^{\circ} 44^{\prime} \mathrm{E}$ & CM \\
\hline $35^{\circ} 10^{\prime} \mathrm{N}$ & $33^{\circ} 23^{\prime} \mathrm{E}$ & 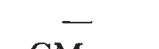 \\
\hline - & - & CM \\
\hline $40^{\circ} 05^{\prime} \mathrm{N}$ & $20^{\circ} 20^{\prime} \mathrm{E}$ & - \\
\hline $47^{\circ} 15^{\prime} \mathrm{N}$ & $21^{\circ} 53^{\prime} \mathrm{E}$ & GENC \\
\hline $\begin{array}{l}35^{\circ} 45^{\prime} \mathrm{N} \\
\text { "SSE of }\end{array}$ & $\mathrm{Oo}^{\circ} 39^{\prime} \mathrm{W}$ & NWA \\
\hline $\begin{array}{l}\text { SSE of } \\
\text { (? Maz }\end{array}$ & $\begin{array}{l}\text { Mazag } \\
\text { gan) }\end{array}$ & NWA \\
\hline $33^{\circ} 19^{\prime} \mathrm{N}$ & ${ }^{08^{\circ}} 35^{\prime} \mathrm{W}$ & \\
\hline $41^{\circ} 59^{\prime} \mathrm{N}$ & $14^{\circ} \mathrm{O} 8^{\prime} \mathrm{E}$ & $\mathrm{CM}$ \\
\hline $3^{8^{\circ}} 06^{\prime} \mathrm{N}$ & $13^{\circ} 20^{\prime} \mathrm{E}$ & $\mathrm{CM}$ \\
\hline $40^{\circ} 5^{8^{\prime} N}$ & $15^{\circ} \mathrm{OI}^{\prime} \mathrm{E}$ & CM \\
\hline $43^{\circ} 12^{\prime} \mathrm{N}$ & $27^{\circ} 28^{\prime} \mathrm{E}$ & GESE \\
\hline $34^{\circ} \mathrm{O} 2^{\prime} \mathrm{N}$ & ${ }^{o 6^{\circ}} 5^{I^{\prime}} \mathrm{W}$ & NWA \\
\hline $4^{\circ} 07^{\prime} \mathrm{N}$ & $\mathrm{or}^{\circ} 4 \mathrm{o}^{\prime} \mathrm{W}$ & GESW \\
\hline $4 \mathrm{I}^{\circ} 5 \mathrm{I}^{\prime} \mathrm{N}$ & $14^{\circ} \mathrm{o6} 6^{\prime} \mathrm{E}$ & CM \\
\hline $3^{6^{\circ}} 4^{6^{\prime} N}$ & $05^{\circ} 10^{\prime} \mathrm{W}$ & ? SIB \\
\hline $45^{\circ} 3^{8^{\prime} \mathrm{N}}$ & $\mathrm{OI}^{\circ} \mathrm{O} 2^{\prime} \mathrm{W}$ & GESW \\
\hline $34^{\circ} 5^{0^{\prime} \mathrm{N}}$ & $00^{\circ} I^{\prime} \mathrm{E}$ & NWA \\
\hline $4^{6^{\circ}} 47^{\prime} \mathrm{N}$ & $02^{\circ} 03^{\prime} \mathrm{W}$ & GESW \\
\hline $43^{\circ} 10^{\prime} \mathrm{N}$ & $\mathrm{OI}^{\circ} \mathrm{I}^{\prime} \mathrm{W}$ & Pyrenees \\
\hline $44^{\circ} \mathrm{O} 4^{\prime} \mathrm{N}$ & $07^{\circ} 15^{\prime} \mathrm{E}$ & GESW \\
\hline $3^{6^{\circ} 2 I^{\prime} N}$ & $44^{\circ} \mathrm{Io}^{\prime} \mathrm{E}$ & WAS \\
\hline $52^{\circ} 04^{\prime} \mathrm{N}$ & $10^{\circ} \mathrm{OI}^{\prime} \mathrm{E}$ & GENC \\
\hline $40^{\circ} 54^{\prime} \mathrm{N}$ & $04^{\circ} \mathrm{Oo}^{\prime} \mathrm{W}$ & NIB \\
\hline $40^{\circ} 44^{\prime} \mathrm{N}$ & $08^{\circ} 35^{\prime} \mathrm{E}$ & CM \\
\hline $34^{\circ} 37^{\prime} \mathrm{N}$ & $0 \mathrm{I}^{\circ} 2 \mathrm{I}^{\prime} \mathrm{W}$ & NWA \\
\hline $45^{\circ} 00^{\prime} \mathrm{N}$ & $14^{\circ} 55^{\prime} \mathrm{E}$ & GESE \\
\hline $40^{\circ} 30^{\prime} \mathrm{N}$ & o6 ${ }^{\circ}$ Io $^{\prime} \mathrm{W}$ & NIB \\
\hline $44^{\circ} 42^{\prime} \mathrm{N}$ & $23^{\circ} 19^{\prime} \mathrm{E}$ & GESE \\
\hline $35^{\circ} \mathrm{O} 2^{\prime} \mathrm{N}$ & $\mathrm{oo}^{\circ} 45^{\prime} \mathrm{W}$ & NWA \\
\hline $35^{\circ} 45^{\prime} \mathrm{N}$ & $05^{\circ} 5^{\prime} \mathrm{W}$ & $?$ \\
\hline $46^{\circ} 46^{\prime} \mathrm{N}$ & $10^{\circ} 17^{\prime} \mathrm{E}$ & Alps \\
\hline $34^{\circ} \mathrm{I} 6^{\prime} \mathrm{N}$ & $04^{\circ} \mathrm{OI}^{\prime} \mathrm{W}$ & NWA \\
\hline $40^{\circ} 3^{8^{\prime} \mathrm{N}}$ & $22^{\circ} 59^{\prime} \mathrm{E}$ & - \\
\hline $33^{\circ} 15^{\prime} \mathrm{N}$ & $05^{\circ} 09^{\prime} \mathrm{W}$ & Atlas \\
\hline $40^{\circ} 20^{\prime} \mathrm{N}$ & $36^{\circ} 35^{\prime} \mathrm{E}$ & WAN \\
\hline $42^{\circ} 33^{\prime} \mathrm{N}$ & $02^{\circ} 23^{\prime} \mathrm{E}$ & GESW \\
\hline $42^{\circ} 34^{\prime} \mathrm{N}$ & $23^{\circ} \mathrm{I} 7^{\prime} \mathrm{E}$ & GESE \\
\hline $\begin{array}{r}35 \mathrm{~km} . \\
\text { Ouzu a }\end{array}$ & $\begin{array}{l}\text { east of Tizi } \\
t\end{array}$ & \\
\hline $36^{\circ} 44^{\prime} \mathrm{N}$ & $04^{\circ} 05^{\prime} \mathrm{E}$ & NWA \\
\hline 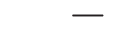 & & Atlas \\
\hline
\end{tabular}

Stabilisation

GENC

GENC?

Pyrenees

NWA

NWA

GENC

CM

ENC

NWA

$33^{\circ} 19^{\prime} \mathrm{N} \quad 08^{\circ} 35^{\prime} \mathrm{W}$

$41^{\circ} 59^{\prime} \mathrm{N} \quad \mathrm{I} 4^{\circ} \mathrm{O} 8^{\prime} \mathrm{E}$

CM

$\mathrm{CM}$

GESE

NWA

GESW

CM

? SIB

NWA

GESW

$43^{\circ} \mathrm{IO}^{\prime} \mathrm{N}$ or ${ }^{\circ} 4^{\prime} \mathrm{W}$ Pyrenees

$36^{\circ} 21^{\prime} \mathrm{N} \quad 44^{\circ} \mathrm{IO}^{\prime} \mathrm{E}$

$52^{\circ} \mathrm{O} 4^{\prime} \mathrm{N} \quad 10^{\circ} \mathrm{OI}{ }^{\prime} \mathrm{E}$

$40^{\circ} 54^{\prime} \mathrm{N}$

$40^{\circ} 44^{\prime} \mathrm{N} \quad 08^{\circ} 35^{\prime} \mathrm{E} \quad \mathrm{CM}$

$34^{\circ} 37^{\prime} \mathrm{N} \quad \mathrm{OI}^{\circ} 2 \mathrm{I}^{\prime} \mathrm{W}$ NWA

$45^{\circ} 00^{\prime} \mathrm{N} \quad 14^{\circ} 55^{\prime} \mathrm{E} \quad$ GESE

$40^{\circ} 30^{\prime} \mathrm{N} \quad 0^{\circ}{ }^{\circ} \mathrm{o}^{\prime} \mathrm{W} \quad \mathrm{NIB}$

$35^{\circ} \mathrm{O}^{\prime} \mathrm{N} \quad \mathrm{oO}^{\circ} 45^{\prime} \mathrm{W}$ NWA

$35^{\circ} 45^{\prime} \mathrm{N} \quad 05^{\circ} 5^{\prime} \mathrm{W}$ ?

$46^{\circ} 46^{\prime} \mathrm{N} \quad 10^{\circ} 1^{\prime} \mathrm{E} \quad$ Alps

$34^{\circ} \mathrm{I}^{\prime} \mathrm{N} \quad 04^{\circ} \mathrm{OI} \mathrm{I}^{\prime} \mathrm{W}$ NWA

$33^{\circ} 15^{\prime} \mathrm{N} \quad 05^{\circ} \mathrm{O} 9^{\prime} \mathrm{W}$ Atlas

$40^{\circ} 20^{\prime} \mathrm{N} \quad 36^{\circ} 35^{\prime} \mathrm{E}$ WAN

$42^{\circ} 33^{\prime} \mathrm{N} \quad 0^{\circ} 23^{\prime} \mathrm{E} \quad$ GESW

$42^{\circ} 34^{\prime} \mathrm{N} \quad 23^{\circ} \mathrm{I} 7^{\prime} \mathrm{E}$ GESE

Ouzu at

Atlas 